\title{
Corporations and the Intertemporal Conflict of Laws
}

\author{
John K. McNulty*
}

$\mathrm{W}$

HEN A LEGISLATURE, court or other lawmaking body adopts, repeals or annends a law, questions arise concerning the temporal limits of the new law's application. The most commonly recognized question is that of retroactivity, or the extent to which the new law will apply to events which occurred before its effective date. In the corporate law context the basic questions are how far new legislative and judicial rules will govern pre-existing corporations, prior investments, and corporate transactions commenced or consummated before the change of law. When articles of incorporation or bylaws are amended by shareholders or directors, similar questions of temporal apphication arise. Adoption of new articles or bylaws poses the problems of when (1) shareholders or directors may affect the structure or activities of an existing corporation, and (2) new articles or bylaws will apply to holders of outstanding shares as well as to holders of shares issued after the new articles or bylaws are adopted. Conflicts between old and new articles or bylaws can raise complex problems of dual retroactivity if a legislative change creates in the shareholders the power to amend an article or bylaw provision, and the shareholders then exercise that power to impose new restrictions on prior investors. This possibility raises the question: To what extent should the state's power to inipose new rules on pre-existing corporations or with respect to past events be delegable to shareholders or directors?

Although corporation law presents many of the intertemporal conflicts problems found in other areas of the law, special complications are presented by the power of corporations to govern themselves by enacting internal laws for the institution. From the Dartmouth College case ${ }^{1}$ to the present, resolution of intertemporal conflicts of corporation statutes, court decisions and internal laws has traditionally been approached in a mechanical fashion which obscures the problems of intertemporal corporation law and of intertemporal law more generally. This article will explore intertemporal choice of law in the corporate context with particular eniphasis on the process of amending articles of incorporation or by laws. The purpose is to determine those factors which ought to be

*A.B., 1956, Swarthmore College; LL.B. 1959, Yale University; Acting Professor of Law, University of California School of Law, Berkeley.

1 Trustees of Dartunouth College v. Woodward, 17 U.S. (4 Wheat.) 518 (1819). See text accompanying notes 52-76 infra for an elaboration of the issues in this case as an intertemporal law problem. 
considered in resolving problems of intertemporal conflict of laws generally, and to deinonstrate that these problems can be effectively analyzed by analogizing them to the territorial choice-of-law issues which constitute the traditional subject matter of conflict of laws. ${ }^{2}$

I

TRANSITIONAL RULES VIEWED AS A CHOICE-OF-LAW PROBLEM

Transitional rules of law govern the reach of new laws backward and forward through time. Some take the form or rules or presumptions for construing statutes or judicial decisions if their intended temporal scope is not clear. ${ }^{3}$ Others, such as constitutional rules, limit the permissible temporal scope of legal rules. ${ }^{4}$

2 Intertemporal problems are of two kinds. In one, the law has changed, and a choice must be made whether to apply the old or the new rule to the given case. This choice is usually phrased in terms of retroactivity and prospectivity. The second kind of intertemporal choice of law problem arises without a change in the law but because the relevant facts of a given case have changed during a period of time.

The contemporaneous ownership rule of shareholder derivative usits is an example of an instance in which the existence or absence of legal rights depends on when legally relevant events occurred rather than upon a change in the law. See FED. R. CIV. P. 23(b); cf. Gresov v. Shattuck Denn Mining Corp., 40 Misc. 2d 569, 243 N.Y.S.2d 760 (Sup. Ct. 1963) (shareholder was contemporaneous owner at time of wrong and at time of suit but had sold and repurchased while the suit was pending; held: he could not maintain the action).

Rules like the contemporaneous ownership rule that have built in temporal boundaries may also give rise to intertemporal problems of the first type when they are adopted, repealed or amended. When both types of intertemporal problems arise in the same case, there is a hybrid conflict analogous to that in some cases in which interterritorial conflicts give rise to intertemporal problems. See the reference to "conflict mobile" cases in note 13 infra.

This article is addressed to the first kind of intertemporal law problem: where a legal rule-statutory, judicial or private-has changed and the question is whether the old or the new rule will govern the rights and habilities arising out of events occurring while the old rule was in effect.

3 As to the general "strong but rebuttable" presumption that a statute is not intended to have retroactive effect, see MAXwELI, INTERPRETATION OF STATUTES 204-20 (11th ed. 1962).

The question of the intended temporal scope of a law is basically a question about its meaning. It is therefore anterior to the question of the validity of that scope. Often, as in other areas, it comes down to issues of statutory interpretation. If the statute is clearly intended to apply only to situations whose operative facts postdated enactment of the statute, the problem of retroactivity is not present. The choice of law problem has been solved by the legislature and solved in a manner which raises no intertemporal problem of the kind under discussion here. Similarly, if a sharcholder amendment by its terms applies only to shares thereafter issued, the conflict has been resolved in an unobjectionable way. If, in contrast, there is no clear evidence of temporal scope in the terms of the statute or shareholder resolution, a further attempt must be made to ascertain intent from evidence drawn froin the lawmaking process, a continuation of the interpretation process. For an intertemporal analysis of New York's dividend statute and a series of amendments in terms of statutory construction and legislative intent, see Randall v. Bailey, 288 N.Y. 280, 43 N.E.2d 43 (1942).

4 Equal protection and reasonable classification problems may follow from intertemporal limits on new law. For a brief consideration of the inequalities which may result when a rule 
In American jurisprudence, constitutional rules of transition have become the primcipal, almost the exclusive, focus of attention on intertemporal legal problems. The United States Constitution contains a number of relevant limitations. For example, a criminal law sanctioning conduct which was lawful when engaged in violates the prohibitions against ex post facto laws. ${ }^{5}$ A state regulation which interferes with continuing legal relationships created by a contract entered into before the effective date of the statute is likely to run afoul of the obligation of contracts clause. ${ }^{6}$ And a new law which materially affects the ownership of previously acquired property may constitute a prohibited deprivation of property without due process of law. ${ }^{7}$

Within these constitutional limits, a new law operates in and through time according to the expressed or imphed intent of its creators and the transitional rules employed by those who apply the law. ${ }^{8}$ Legislative intertemporal techniques, such as "savings clauses," or "grandfather

is enforced differently according to the various times when events occurred and there has been reliance upon contemporaneous law, see Knetsch v. United States, 348 F.2d 392 (Ct. Cl. 1965).

The equal protection argument is often phrased in terms of "class legislation." For example, in Muller v. Theodore Hamm Brewing Co., 197 Minn. 68, 268 N.W. 204 (1936), the corporation was organized prior to the adoption of a new business corporation act in 1933. The 1933 act provided that it was not to be immediately applicable to pre-existing corporations, but that it would be conclusively presumed to be applicable to pre-existing corporations after one year unless a majority of the shareholders filed an election not to be bound by the new law. One shareholder, who wanted to take advantage of the cumulative voting provisions of the new act, contended that the exemption amounted to class legislationan arbitrary distinction between electing and nonelecting corporations. The court rejected plaintiff's contention almost summarily. Cf. French v. Cumberland Bank \& Trust Co., 194 Va. 475,74 S.E.2d 265 (1953), where a legislative modification of the vote required to change cumulative to straight voting was made applicable only to banks upon which cumulative voting had been imposed as a condition of a loan from the Reconstruction Finance Corporation. This application was held not to be class legislation over a claim by a shareholder who purchased prior to the legislative ehange.

5 U.S. Consr. art. I, $\S \S 9,10$.

6 U.S. Consr. art. I, § 10[1].

7 U.S. Const. amends V \& XIV, \& 1 .

${ }^{8}$ Sometimes the policy of the law implies an intent or purpose that it be applied to events preceding its enactunent or to the continuing effects of those events (as in the instance of government contract renegotiation laws and mortgage moratorium legislation). When the issue is one of statutory interpretation and the legislature's intention has not been made explicit, the question presented to a court is whether the destruction or impairment of existing rights, privileges or obligations is material to the achievement of the statutory objectives. If not, a construction against retroactive application is to be preferred.

${ }^{9} \mathrm{~A}$ savings clause preserves pre-existing law as to specified prior cases or situations. Legislatures often use the savings clause device to solve the intertemporal problem that arises when a change in the law, such as a repeal, would otherwise affect an accrued or filed cause of action. The federal statutory savings clause for repealing statutes is at $61 \mathrm{Stat.} 635$ (1947), 1. U.S.C. § 110 (1964). See generally LeNhofF, Cases on Legistation 351 (1949).

An example of the need for such a savings clause is Coombes v. Franklin, 213 Cal. 164, 
clauses, "10 ameliorate the unfairness of laws which would otherwise be retroactive. Courts have developed exceptions to the usual disfavor with which retroactive legislation is viewed. Legitimating, validating or "curative" laws, as well as those which are found to be "clarificatory only," are

1 P.2d 992 (1931), rev'd sub nom., Coombes v. Getz, 285 U.S. 434 (1932). The United States Supreme Court there held that the repeal of $\$ 3$ of article XII of the California Constitution, which imposed personal liability on corporate directors for money embezzled or misappropriated by corporate officers, could not prevent a creditor who had brought suit while $\S 3$ was in force from maintaining his suit. The creditor's vested property right or contractual claim was protected both by the obligation of contracts clause and the due process clause of the fourteenth amendment against "retroactive" apphication of the new California law. The Coombes case seems to put a priority on instigation of suit before a change in the law, but the opinions are not clear that it was filing the action rather than merely extending the credit under prior law that "vested" the creditor's right in application of $\S 3$ of article XII. The rigidity of Coombes and its viability as precedent has been questioned. See Slawson, Constitutional and Legislative Considerations in Retroactice Lawmaking, 48 CALIF. L. REv. 216, 232 (1960).

Cf. Meyer \& Holler v. Ramona Village, 5 Cal. App. 2d 679, 43 P.2d 823 (1935), which held that the repeal of $\S 3$ of article XII, upon which the liability of shareholders of California corporations was predicated, did not relieve shareholders from liability previously incurred. A statutory savings clause was allegedly faulty. The court, however, citing Coombes v. Getz, supra, said that in any event the question of continumg liability was settled in favor of the creditors. The code now protects the rights of creditors in such situations by the successor to the statute involved in Meyer. See CAL. CORp. CODE § 126 providing that neither the enactment, amendinent nor repeal of the corporation laws "shall take away or inpair any liability or cause of action existing or incurred against any corportion, its shareholders, directors, or officers." But see Moss v. Sinith, 171 Cal. 777, 155 Pac. 90 (1916), appeal dismissed sub nom., Moss v. Moore, 246 U.S. 654 (1918), where before plaintiff's judgment against directors for causing the corporation to mcur debts in excess of its subscribed capital stock was inade final, the statute creating the cause of action was repealed; the repeal was held to have abolished directors' liability.

Express or imphed abatement of pending criminal prosecutions by virtue of a repealing statute produces in effect the reverse of a savings clause-notwithstanding that the law in effect at the time of the act constituted a violation, subsequent prosecution, after the life of the prohibition has euded, is avoided. See, e.g., United States v. Chambers, 291 U.S. 217 (1934) (repeal of the eighteenth amendment by the twenty-first amendinent abated prosecutions under the National Prohibition Act); Bell v. Maryland, 378 U.S. 226 (1964) (effect of interveping state statute on state convictions). A case involving implied abatement of state prosecutions by enactment of federal civil rights legislation is Hamm v. City of Rock Hill, 379 U.S. 306 (1964). But see Warring v. Colpoys, 122 F.2d 642 (D.C. Cir.), cert. denied, 314 U.S. 678 (1941).

For related problems in administrative law, see Berger, Retroactive Administrative Decisions, 115 U. PA. L. Rev. 371 (1967); Newman, Should Official Advice Be Reliable?Proposals as to Estoppel and Related Doctrines in Administrative Law, 53 Cosum. L. REv. 374 (1953).

$10 \mathrm{~A}$ grandfather clause preserves prior law as to entities or rights and liabilities formed previously. See, e.g., UNIFORar COMnIERCIAL CODE § 10-102(2): "Transactions validly entered into before the effective date specified in Section 10-101 and the rights, duties and interests fiowing from them remain valid thercafter and may be terminated, completed, consummated or enforced as required or permitted by any statute or other law amended or repealed by this Act as though such repeal or amendinent had not occurred." 
often given retroactive application. ${ }^{11}$ While the reasons for these transitional rules and exceptions have been analyzed by several commentators, ${ }^{12}$ an approach which analogizes intertemporal conflicts problems to those in interterritorial conflict of laws has not been fully articulated. If the temporal boundaries of a new law are viewed as territorial borders, one can speak in terms of an intertemporal conflict of laws, or of a conflict of laws in time. ${ }^{13}$ The first necessary step in resolving a conflict of laws

11 On curative acts in general, see LENHOFF, op. cit. supra note 9 , at 312-23. See also Smith, Retroactive Laws and Vested Rights, 5 Texas L. Rev. 228, 237-240 (1927). In connection with "curative" legislation addressed to defective judicial proceedings some courts have been led to distinguish between retroactive curing of so-called nonjurisdictional irregularities (permissible) and retroactive attempts to cure jurisdictional irregularities (impermissible). Smith, sulpra, at 241. See generally, Note, Retroactive Laws-Remedial Legislation, 11 MERCER L. REV. 235 (1959).

For an example of retroactive application of a curative statute affecting corporate existence, see Lester Bros. v. Pope Realty \& Ins. Co., 250 N.C. 565, 109 S.E.2d 263 (1959), noted 38 N.C.L. Rzv. 270' (1960); cf. Garzo v. Maid of Mist S.S. Co., 278 App. Div. 508, 106 N.Y.S.2d 4 (1951), a case dealing with revival of corporate existence after an apparently inadvertent lapse and failure to renew or extend the charter. "Retroactive" exercise of this right to cure a lapse was upheld.

Other techniques employed by the courts to uphold retroactive legislation are mentioned by Slawson, supra note 9, at 235-38, 242.

12 See, e.g., Fulder, The Morality of Law 51-62, 79-81 (1941). And see sources cited in note 144 infra.

${ }^{13}$ This terminology has found favor in continental literature. See, e.g., Gavarda, Les Conflits dans le Temps en Droit Internationat Privé passim (1955); Lever, Essar de Systématisation du Confuit de Lois dans Ie Temps passim (1959); Roubier, Le Drott Transtrotre passim (1961); RoubIer, Les Conflits de Lors dans le TeMrPs passim (1931); Grodecki, Conflict of Laws in Time, 35 BRIT. Үв. INT'L. L. 58 (1960); Landry, De L'Application de la Loi dans le Temps, 6 Collection des Travaux de ra Faculte de DroIT DE L'UNTVERStTÉ D'OtTaWa 6 (1965); Poetzold, La Jurisprudence Allemande en Mattière de Conflict de Lois dans le Temps, 22 Revoe de Droit International Priví 566 passim (1927); Roubier, Les Confitits dans le Temps en Droit in International Privé, 26 Revue de Drotr Internattonat Prtvé 38 (1931); Szászy, Les Confits de Lois dans le Temps, 47 RECUEII DES CoURS 149 passim (1934). See also Lawson, Zeitablauf als Rechtsproblem, 159 ARCHIV FÜR DIE CTVIITSTISCHE PRAXIS 97 (1970).

The phraseology is uncommon but not unknown in American legal scholarship. See, e.g., Cheatham, Gruswold, Reese \& Rosengerg, Confitct of LaWs 486 n.5 (1964); EhreN2Weig, Conflict of Laws 309 n.2 (1962); Hart \& Sacks, The Legat Prgcess: Basic Problems in the Making and Application of Law 637 (Tent. ed. 1958); LenHoff, op. cit. supra note 9, at 298; 4 Raber, The Conflict of Laws: A Comiparative Study 501-19 (2d ed. 1958); WeBb \& BROWN, CONFLICT OF LAWS 54 (1960).

Much of the writing on intertemporal law has concerned itself with intertemporal problems in interterritorial choice of law cases, "le conflit mobile." See Castel, Conflict of Lawes in Space and Time, 39 CAN. B. REv. 604 (1961); Knittel, The Temporal Dimension in the Confict of Laws Rules, 40 BRIT. Yв. INT'x L. 105 (1964); Mann, The Time Element in the Conflict of Laws, 31 Brrx. Үв. INT'x L. 217 (1954); Spiro, The Incidence of Time in the Conflict of Laws, 9 INT's \& COMPP. L.Q. 357 (1960). See also AFrolter, GescHCHTE DEs intertemaroraten Privatrecers (1902); 4 Raber, op. cit. supra, at 503-19; Stimson, ConFLTCT OF LAWS 3 (1963); WeBb \& BRoWN, CoNfutct of LAWS 54-56, 223, 226 (1960); Wengler, SkJzZEN zUR LeHre vose Statutenwechsei, 23 Zetrscarift für AUSLANdisches 
UND Internationales PRIVATRECHT 535 (1958). A most recent treatment is a summary by Morris, The Time Factor in the Conflict of Laws, 15 INT'L \& COMP. L.Q. 422 (1966), which forms the substance of Chapter 5 ("The Time Factor") in the forthcoming edition of Dicex, CoNflict of LAws. Morris calls attention, in addition to the material cited above, to Anzilotti, La Questione della Rettroattività della Regole di Diritto Internazionale Privato,

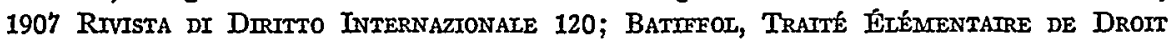
International PrIvé 369-77 (3d ed. 1959); Diena, De la Rétroactivité des Dispositions Législatives de Droit International Privé, 27 JoURNaI dU DroIt INTERNATIONAI 928 (1900); 1 KAEN, DAs zeItITCHe ANWENDUNGSgeBIET DER ÖRTLICHEN KOLIISIONSNORAMEN IN ABhandlungen zUMr Internationalen PrThatrecht 362 (1928); Lewald, Règles Generales des Conflits de Lois, 69 Recuerr DES CouRs 5, 94-99 (1939); Olive, De la Rétroactivité des Règles Juridiques en Droit International, 1892 RevUe DE DROIT INTERNATIONAT ET DE LÉGISLATION COMPARÉE 533 passim. See also Kos-Rabcewicz-Zubkowski, Les Conflits de Lois dans I'Espace et dans le Temps en Matière de Régimes Matrimoniaux dans le Province de Québec, 6 Collection des Travaux de IA Faculté de Droit de L'UnIversité D’OtTowa 15 (1965); Continental monographs cited by Castel, supra, at 605 n.6. Also, Y. Scholten of the Netherlands Bar has referred me to the following literature: BATIFroL, CoNFIIT DE LoIs DANS L'Espace eT Confuts de LoIS DANS IE TEMrs 292 (1950); Batiffol, Confits Mobiles et Droit Transitoire, in Mélanges en L'Honneur de PaUL RoubIER 39 (1961) ; HürdTNAan, Das INTERTEATPORALE GeNOSSENSCHAFTSCRECHT; HÜRITMIAN, BETTRÄGE zUR FRAGE DER ÄNDERUNG atter Aktiengeseitschaften und Genossenschaftsrechten uND Das Revidierte ObitgaTIONENRECHT (1946).

One imtroduction to intertemporal law is given by Stmison, Confucr of LAws 3-15, 252-56 (1963). With the problems of international (interterritorial) conflicts in mind, Stimson asserts that "in any choice of law affecting the result of the lawsuit, the court should select the law to which the parties or property were subject at the time of the conduct or event, the legal effect of which is in question, and not the law to which they or it are subject at the time of the trial." Id. at 3. This generalization seems either circular, vague or wrong, and evidently the author means it to apply only in choice of territorial law cases. See id. at 3-12. But the concern from which it arises is real. As the author states, if all the law in effect at time of trial and only that law were applied, forum-shopping-interterritorially and intertemporally-would present a serious problem. Nevertheless, sometimes it is necessary or desirable to apply the law in effect at the time of trial. Procedural rules are one example. And in the realm of private property or contract riglits, or even torts or wills, the substantive law in effect at the time of trial may often be appropriately applied for the sake of simplicity and equality and to effectuate changes that must occur in the legal system if it is to serve the needs of the community. Corporation law is also one of those areas in which the cases indicate a tendency to apply the law in effect at the time of trial rather than at the time the "cause of action arose" or the time of the conduct or event whose legal effect is in question, unless some special reason for departing from this general rule is shown. See, e.g., cases cited in notes $29,69,131$ and 143 infra. Important or imvited reliance on the then current law is one such special reason. The temporal self-limitation of later law is another.

Perhaps laws dealing with the legality of conduct, such as criminal laws or tort laws, can he distinguished from laws dealing with the extent and nature of economic values resulting from events or legal relations (property, corporations, etc.). If the question facing a court at $T \&$ is whether the act at $T 1$ is illegal, punishable or invalid, perhaps the natural and best tendency is to look to the law as it was at $T 1$. But if the question at T2 is what property interests exist at $T 2$, following a transaction at $T 1$ and an imtervening change in law, perhaps the law of $T \mathscr{Q}$ is the better choice.

In the contert of time and place conflicts, Stimson cites several cases in the United States Supreme Court for the proposition that the full faith and credit and due process clauses of the fourteenth amendment compel the courts of one state to apply the law to which the parties or property were subject at the time of the conduct or event whose legal effect is in question. STImpson, op. cit. supra, at $7-12$. This statement seems to mean that a state would 
in time is to determine the temporal boundaries of the legal rules involved. If some of the legally relevant events occur on one side of the boundary between two rules (for example, if negligence on the part of a hospital occurred before enactment of a statute abolishing charitable immunity) and the rest occur on the other side (additional injuries, complaint, trial and appeal), a decision must be made as to how they are to be weighted. ${ }^{14}$ Such a decision is nothing more than a traditional choice-oflaw decision. ${ }^{15}$ If all the relevant events occurred before the change in

not be free to apply later law of the state of governing law even if that state would do so. In other words, forum 2 would be obliged to apply the forum 1 law as it stood at $T 1$ even though forum 1 would lave applied its law in effect at $\mathrm{T} 2$ to a similar case involving only domestic facts. The cases cited by Stimson, however, do not bear out this reading and simply stand for choices of territorial law based on certain events in a temporal series rather than others: an intertemporal choice of law for the purpose of selecting territorial law. Moreover, they all deal with that area of territorial conflicts involving insurance contracts, cases subject to question even in their territorial conflicts capacity. These cases illustrate the peculiar intertemporal approach of cases laving an interterritorial character as well as an intertemporal one. However, they also illustrate the scheme of the problem. They involve a choice of one operative event, rather than earlier or later ones, for use in reference to applicable legal rules-a selection that is made in "pure" intertemporal cases as well as in mixed temporal and territorial ones.

In Addison v. Addison, 62 Cal. 2d 558, 399 P.2d 897, 43 Cal. Rptr. 97 (1965), a statute which affected marital property riglits was held applicable to a divorce action where the suit was filed prior to its enactment. The court stated that the effect was not to apply the statute retroactively, on the theory that the judgment of divorce was the "operative" fact and it occurred after the change in law. With respect to the Addison case and related choice of law problems, both interterritorial and intertemporal, see Comment, Marital Property and the Conflict of Laws: The Constitutionality of the "Quasi-Community Property" Legislation, 54 CAITF. L. REv. 252 (1966). See also Schreter (now Kay), "Quasi-Commutnity Property" in the Conflict of Laws, 50 CALTF. L. Rev. 206 (1962) ; Note, 18 Stan. L. Rev. 514 (1966). On the pure intertemporal problem, cf. Note, 17 Hastrincs L.J. 815 (1966).

14 See Jeffrey v. Whitworth College, 128 F. Supp. 219 (E.D. Wasl. 1955), which held that the plaintiff may not benefit from change in charitable immunity statute enacted after his injury; defendant's vested rights in law current at time of injury are not to be infringed.

15 As indicated earlier, in large part, questions of intertemporal law begin as questions of interpretation of rules (whether statutes, private rules or judicial decisions). Then, when the intended temporal scope of the statute or decision has been ascertained, its validity under constitutional or nonconstitutional rules can be, and often is, drawn in question. For example, see California cases on the change in governmental immunity for tort liability, such as Muskopf v. Corning Hospital Dist., 55 Cal. 2d 211, 359 P.2d 457, 11 Cal. Rptr. 89 (1961) (abrogating the judicial doctrine of governmental immunity); County of Los Angeles v. Superior Court, 62 Cal. 2d 839, 402 P.2d 868, 44 Cal. Rptr. 796 (1965) (cause of action arose before Muskopf and reduced to suit before moratorium legislation); Loop v. Cahfornia, 240 Cal. App. 2d 591, 49 Cal. Rptr. 909 (1966); Moxon v. County of Kern, 233 Cal. App. 2d 393, $43 \mathrm{Cal}$. Rptr. 481 (1965) (cause of action arose after moratorium legislation and before 1963 legislation); Flournoy v. State, 230 Cal. App. 2d 520, 41 Cal. Rptr. 190 (1964). And see generally, Van Alstyne, Governmental Tort Liability: Judicial Lavomaking in a Statutory Milieu, 15 Stan. L. REv. 163, 230-53 (1963) (analysis of the intertemporal law problems resulting froin the overruling decision and legislative moratorium). See also Nellis, Retroactivity of the 1963 California Governmental Tort Laws: A Legislative Triumph, 1 LINCoLN L. REv. 39 (1965). 
law, a court is likely to hold that the rights arising under the earlier law have "vested,"16 and are "not to be undone," unless the law changed was merely one of "procedure" or "reinedy" rather than one of "substance" or "right."17 But what is procedural and what is substantive is a mystery

16 The parallel of this analysis to the "vested rights" approach in the First Restatement, Conflict of Laws and, to a somewhat lesser extent, the Second Restatement, to interterritorial choice of law problems is unmistakable. On the vested rights character of the restatenents see, e.g., Cavers, The Choice-OF-Law Process 5 n.12, 8 n.20 (1965); Ehrenzweig, The Second Conficts Restatement: A Last Appeal for Its Withdrawal, 113 U. PA. L. REv. 1230 (1965); Ehrenzweig, American Conficts Law in Its Historical Perspective, Should the Restatement Be "Continued"? 103 U. PA. L. REV. 133 (1954).

${ }^{17}$ See, e.g., Clews v. Stiles, 181 F. Supp. 172 (D.C.N.M. 1960) (nonresident service of process statute whose effective date was after automobile accident but before suit filed held substantive); Spriggs v. Dredge, 74 Ohio L. Abs. 264, 140 N.E.2d 45 (1955) (survival wrongful death statute held substantive). See illustrative cases collected in EHRENZWErG, Confutct of Laws 309 n.2 (1962); cf. Estate of Thramin, 80 Cal. App. 2d 756, 183 P.2d 97 (1947) ; Byler v. Hershman, 156 Misc. 349, 281 N.Y. Supp. 942 (N.Y. City Ct. 1935). This procedure-substance dichotomy parallels cases distinguishing matters of remedy from matters of substantive right and holding, for example, that a statute affecting a "remedy" but not the "right" may be applied "retroactively." See, e.g., Laird v. Carton, 196 N.Y. 169, 89 N.E. 822 (1909); cf. Hollenbach v. Born, 238 N.Y. 34, 143 N.E. 782 (1924). See also Smith, supra note 11 , at $239-43$.

The right-remedy distinction has also been employed in connection with legislation affecting private contracts and remedial rights growing out of the contracts. See, e.g., Home Bldg. \& Loan Ass'n v. Blaisdell, 290 U.S. 398 (1934). While the contract clause of article $1, \S 10$, does not apply to the Congress and therefore the right-remedy distinction does not arise under that clause, comparable limits of the due process clause of the fifth amendment have also been considered somewhat in right-remedy terms. See, in connection with the Frazier-Lemke Act $\$ 75,47$ Stat. 1470 (1933), and its application to a pre-existing mortgage, Louisville Joint Stock Land Bank v. Radford, 295 U.S. 555 (1935) ; Wright v. Vinton Branch Bank, 300 U.S. 440 (1937); Wright v. Union Central Life Ins. Co., 311 U.S. 273 (1940). A parallel distinction in the corporate area seems to have been made between changes in the law affecting remedies rather than substantive rights. See cases cited in 7 FLETCHER, CoRporaTIONS \$ 3665 (1964).

Statutes dealing with what inight be regarded conceptually as a matter of remedy often are denied "retroactive" application, however, if the effect of applying them to cases having antecedent operative facts is effectively to cut off the "right" or substantially to affect the liability of the parties. See, e.g., People v. Cohen, 245 N.Y. 419, 157 N.E. 515 (1927). This phenonienon has two components. The first is a recognition that a matter conceptually mvolving remedies may in fact have an outcome determinative effect: To limit or deny the remedy may be to deny the right. $C f$. Ettor v. Tacoma, 228 U.S. 148 (1913). The second is an apparently greater willingness to change the legal consequences of past events when the effect is to benefit a private interest vis-à-vis the state (not vice versa), or to enlarge or preserve the opportunities for a private elaimant to recover from another private party. Both components are illustrated by cases that seen more ready to apply a new statute of limitations to pre-existing causes of action or judgments when the statute extends the limitation period (and the first period has not run at the time the extension first becomes effective) than when it contracts it. See Chase Sec. Corp. v. Donaldson, 325 U.S. 304 (1945); Grahain \& Foster v. Goodcell, 282 U.S. 409 (1931); Davis v. Mills, 194 U.S. 451 (1904); Campbell v. Holt, 115 U.S. 620 (1885); People v. Cohen, supra. See also LENHoFr, op. cit. supra note 9, at 323; cases collected in Annot., 133 A.L.R. 384 (1941). Chase Sec. Corp. v. Donaldson, supra, held that expansion or contraction of the limitation period may constitute a depriva- 
no shallower in this context than in Erie v. Tompkins or interterritorial choice-of-law problems. ${ }^{18}$

An advantage of thinking of intertemporal problems in choice-of-law terms is that it invites consideration of options rather than mechanical formulas. Contemporary conflict of laws thinking is not content with merely determing whether rights are "vested."10 Similarly, an intertemporal choice-of-law approach would not stop with the simplistic inquiry whether the new law is or is not retroactive. ${ }^{20}$ Rather, in deciding

tion of property ("vested property rights") without due process of law in violation of the fourteenth amendment. Revival of expired claims can present similar problems. See Gange Lumber Co. v. Rowley, 326 U.S. 295 (1945).

A distinction has been adumbrated between private rights and public rights even if both are establislied by judgment of a court. Private rights, in contrast with public rights, are considered vested and hence may not be destroyed by subsequent legislation. See Hodges v. Snyder, 261 U.S. 600 (1923). Lenhoff suggests that this distinction voices the difference between cases involving particular damage to a private hitigant and cases involving the general public. LENHOFF, $0 p$. cit. supre note 9 , at 347 . This difference is paralleled by the difference between legislative amendment of the general corporation law and amendment of the charter by majority-sliarcholder action.

18 See generally the discussion of the vested rights doctrine and distinctions between, on the one hand, matters of procedure and evidence and, on the other hand, substance and vested riglits with particular respect to changed rights of appeal and statutes of limitations in Kavanagh, Retrospective Operation of Law, 6 Colcection des TravauX de IA Faculti DE Droit de L'Université D'OtTAwa 28, 34-38 (1965). Professor Kavanagh persuasively advocates a "purposive" or functional approach in interpreting the temporal scope of statutes. He then suggests a weighing process (in the absence of constitutional rules) to balance the injury to one litigant if a rule is applied retroactively against the interests of the other litigant and/or the state in having a retroactive application.

One typical attempt to deal with change of law problems in terms of procedure and substance-an attempt which exposes the sterility of that approach-is Druker, The Question of Damages Resulting from Recent Legislative Changes, 15 DRakx L. REv. 107, 110-11 (1966).

10 The vested rights approach tends to identify the issue of retroactivity witl the protectibility of the rights in question. The circularity of this approach has long been recognized. See, e.g., LeNrofr, op. cit. supra note 9, at 378 and cases collected therein; Greenblatt, Judicial Lintitations on Retroactive Civil Legislation, 51 Nw. U.L. REv. 540 (1956). As lias often been observed, the vested rights concept simply refers to riglits protected against legislative interference, but does not provide a useful independent test for their prior identification; it serves better to classify decided cases than to analyze or predict the outcome of new ones.

The legal sources of such rights may be constitutional (due process clauses, contracts clauses) or nonconstitutional (fairness, property). Ultimately the vested rights or contract clause decisions seem to result from a balancing of mterests much as decisions in interterritorial choice of law cases, formerly employing vested rights language, are now seen to result from a weighing of the governmental interest or an analysis of the policies for choice of local or foreign law. See, e.g., City of El Paso v. Simmons, 379 U.S. 497 (1965) (riglit to rcinstatement of forfeited lands restricted by statute uplield despite the fact that it "technically" altered an obligation of the contract).

${ }^{20}$ See, e.g., Greenblatt, supra note 19, at 561. Compare, e.g., Gottlieb v. Heyden Cliem. Corp., 33 Del. Ch. 283, 92 A.2d 594 (Sup. Ct. 1952), where the Delaware Supreme Court used retroactivity language to uphold a stock option plan that entailed amendment to a certificate of imcorporation to eliminate the pre-emptive rights of lolders of outstanding 
whether to apply a new statute to earlier acts or to construe an overruling of precedent as having only prospective operation, a legislature, court or administrator can consider the relevant facts and policy considerations, such as reliance and expectation interests, simplicity and cost of judicial administration, and accomplishment of the purpose of the new rule. In contrast, the traditional approach results in a meclianical preoccupation with himits on retroactivity which distracts attention from the central policy question of whether a rule slould be given the temporal scope at issue. $^{21}$

An analysis of "retroactive" clioice-of-law decisions requires an understanding of the notion of retroactivity, which raises the question, retroactive with respect to what? ${ }^{22}$ A new rule of evidence or of pleading or

shares to purchase authorized but previously unissued shares. The Delaware court simply said that the charter amendment in Gottlieb was "purely prospective" in its operation and therefore valid as a matter of intertemporal law.

21 This is not to say, however, that concern with limits can or should be altogether avoided in a jurisdiction liaving a written constitution which expresses some rules on the subject. Accordingly, much of the literature from jurisdictions not subject to constitutional rules limiting intertemporal choice of law decisions, see note 13 supra, cannot be projected directly into our jurisprudence. However, the theoretical structure and many of the inquiries remain pertinent to the problems faced in evaluating constitutional limits and in making intertemporal choice of law decisions within the constitutional system.

One colloquium has noted the similarities with respect to attitudes and rules on retrospective operation of law between Canadian civil law systems and Canadian common law systems. See Hubbard, General Discussion of the Retrospective Operation of Law, 6 Collection des Travaux de la Faculté de DroIT de L'Université D'OtTaWa 42 (1965); cf. Ducharme, Discussion Des Rapports, id. at 46.

22 This question shows a concern with the nature of the events that antedate the new rule. This concern resembles the localization process in interterritorial choice of law problems. There, localization of the connecting factor is simply the process of determining which event in a multistate problem is thought to be the relevant one under a given choice-of-law rule, and then determining in what place that event occurred. See generally EBRENzwerg, CoNFIICT of LAws 326, 333-34 (1962). For example, one choice-of-law "rule" in contract law stated that the validity of a contract is governed by the law of the place of contracting. But it is not always obvious what that place was if the offer was made in one state and accepted in another and notice of acceptance was mailed to the offeror in a third state. So the process of localization may itself be a question involving choice of law questions: Which law governs the question when, and therefore where, a contract is made? This problein has a distinct parallel in intertemporal law.

The utility of analyzing retroactivity in terms of the question "Retroactive with respect to what?" is illustrated by a distinction made by Kavanagh, supra note 18, at 29. Professor Kavanagh argues that a statute imposing a ten dollar tax upon admission to the bar would operate "retroactively" if applied to someone admitted prior to enactment of the statute. A new obligation would be created on the basis of a past transaction, namely prior admission to the bar. But, he argues, a new statute providing that every lawyer shall pay an annual tax of ten dollars would not operate retroactively, even if applied to a person admitted to the bar prior to enactinent of the statute. This statute, in his view, merely declares that in the future a tax shall be paid (no tax to be imposed for former years of practice).

To he sure, there are conceptual differences between these two hypothetical statutes, but for some practical purposes the statutes do not differ from one another. Not ouly would both 
of courtroom procedure which has been adopted between the time the facts giving rise to litigation occurred and the time the case is tried can often be applied without any injustice, even thougl the change may have a material impact on the outcome of the case. If no reliance or expectation tied the earlier events to the coexisting procedural law, the application of the later law is both convenient and unobjectionable. But if, at the time the earlier events took place, reliance was placed on rules of law then in effect, later application of different rules may be undesirable. This proposition is phrased conditionally since reliance interests must often give way to more weiglity pohicies cognizable at the later time. ${ }^{23}$

Several modern theories of territorial choice of law look to the policy of the forum and use it to support application of the forum's substantive law unless (1) the forum does not have an interest in the outcome of the litigation, and there is another state which does have such an interest, ${ }^{24}$ (2) the policy of the forum with respect to the type of transaction in question requires that the substantive rules of the foreign state govern, ${ }^{25}$

collect the same revenue from the same people, but both statutes would be "retroactive" with regard to some of the same-important-events, namely, the imvestment of time and money and human energy on the part of law students and licensed practitioners.

Similarly, a change in corporation law can seem to be prospective because it speaks only of shareholder votes held in the future or pre-emptive rights as to future share issues. It does not seem to undo past shareholder votes or remove or impose pre-emptive rights or share transfer restrictions in connection with past issues or transfers. With respect to these events the law is prospective. But in terms of investment expectations, contractual rights or reliance imterests developed either when the corporation was formed or the imvestments in shares made, the new rule has a retroactive impact which must be recognized in evaluating the constitutionality and desirability of applying the new rule to corporations in existence or to shares outstanding when the statute is enacted.

${ }^{23}$ See text following note 155 infra.

24 See, e.g., Currie, Notes on Methods and Objectives in the Conflict of Laws, 1959 DURe L.J. 171, 178, reprimted in CURRIE, SELECTEd Essays on the ConfuICT of LAws ch. 4 (1963). A parallel between intertemporal and interterritorial choice of law decisions and the manner in which an interterritorial choice of law may involve questions of retroactivity has been suggested by Professor Currie in The Verdict of Quiescent Years: Mr. Hill and the Confict of Laws, 28 U. Car. L. REv. 258, 290-293 (1961). His analysis has been criticized. See M. Traynor, Confict of Laws: Professor Currie's Restrained and Enlightened Fortm, 49 CaLIF. L. Rev. 845 (1961). Currie subsequently modified his position somewhat witl respect to the case analysis be used in Quiescent Years, supra. See CurrIE, Serectzd Essays On The Confuict of Laws 739 (1963), originally published in 1963 DuRE L.J. 1. However, this reconsideration does not affect the similarity he noted between interterritorial and intertemporal choice-of-law decisions.

25 Ehrenzweig, Comments on Babcock v. Jackson, A Recent Development in Conflict of Laws, 63 Colvar. L. Rev. 1243 (1963); Ehrenzweig, Choice of Law: Current Doctrine and "True Rules" 49 CALIF. L. Rev. 240 (1961).

The forum's transitional rules may stem from the forum's current domestic substantive law rules and from exceptions to the application of current substantive law, just as territorial choice-of-law rules are appropriately viewed as exceptions from the applicability of domestic substantive rules of the forum. Cf. Errenzwerc, Confuters In a Nutsherr $\S 9$, at 40 (1965); EমRENZWETG, CoNfITCT of LAWs §§ 102-08 (1962). Thus, the forum always first applies 
or (3) the content of the applicable foreign rules with respect to the particular case is preferable to that of the forum rules. ${ }^{26}$ The forum $\mathrm{m}$ an intertemporal conflict of laws case must make a similar choice-of-law policy decision. This decision, by hypothesis made at the later time, should reflect the policy of the forum at that time. Usually its policy is to apply the current, newer, and presumably better law to all cases, even those involving significant events which occurred before the change in law. But the policy of the forum at the later time may include protection of interests developed on the strength of prior law. In determining such an application of the new law, the forum should inquire into the purpose of the new rules, whether that purpose will be undercut by exceptions for cases, such as that at hand, and the extent of the forum's interest at the later time in protecting the expectations and investments induced or reasonably developed earhier. ${ }^{2 \tau}$

The development of intertemporal or transitional rules in corporation law has reflected a shift from (1) fixed rules which tied the legal significance of events to the law existing at the time of their occurrence (the lex praeterita) through (2) a more flexible case-by-case approach in which some examination was made of the consequences of applying coexisting or subsequent law (the lex praesens), and finally to (3) an ostensible freedom from intertemporal hmitation reflected in recent cases, such as $T u$-Vu Drive-In Corp. v. Ashkins. ${ }^{28}$ This freedoin, however, may be more apparent than real.

(or makes) current intertemporal choice of law rules just as it always applies (or makes) its own interterritorial choice of law rules in the first instance.

26 See, e.g., Cavers, The ChoICE-OF-LaW Process (1965); Leflar, Choice-Influencing Considerations in the Conflict of Laws, 41 N.Y.U.L. REv. 267 (1966); Leflar, Conflicts Law: More on Choice-Influencing Considerations, 54 CALIF. L. REv. 1584 (1966).

27 Two New York cases lend themselves readily to an intertemporal choice of law conceptualization in these terms. In both, old law rather than the law in effect at the time of the decision was held applicable.

In Garden State Brickface \& Stone Co. v. Oradell Construc. Corp., 44 Misc. 2d 22, 252 N.Y.S.2d 790 (Sup. Ct. 1964), the court held that an unqualified foreign corporation that allegedly was doing business in New York could not be barred from enforcing a contract inade in New Jersey in 1958, even though the existing law in New York when the decision was rcached precluded such a corporation froin enforcing such a contract in New York courts. The reason for the decision was that the law in effect when the contract was inade restricted access to the courts only with respect to contracts made in the state. The change in law had occurred on September 1, 1963, when the New York Business Corporation Law went into effect.

Similarly, in Tetreault v. State, 50 Misc. 2d 170, 269 N.Y.S.2d 812 (Ct. Cl. 1966), an unqualified foreign corporation was permitted access to New York courts to sue for damages sustained in a 1963 traffic accident, despite the fact that the law in effect at the time of decision barred unqualified corporations from maintaining any action in the state, because the old law was inapplicable to tort claims.

28 See note 29 infra. 


\section{INTERTEMPORAL CORPORATIONS IAW}

\section{A. An Illustration}

Tu-Vu Drive-In Corp. v. Ashkins, ${ }^{29}$ a 1964 California case involving bylaw amendments restricting the transfer of shares, illustrates some problems of intertemporal conflict of laws in the corporate context. The $T u-V u$ case raised the question "whether a corporation may enforce a bylaw restricting alienation of stock against a nonconsenting stockholder who acquired his stock prior to the enactment of the bylaw." ${ }^{130}$ The minority shareliolder (Mrs. Aslikins) purchased her shares in 1958, when the corporation was formed and the original articles and bylaws adopted. At that time a lolder of authorized, issued and outstanding shares could give, sell or pledge his shares without first offering thein to the other shareholders or the corporation on the same terms. Durmg the relevant period of time in $T u-V u$ the California corporation law permitted the original articles $^{31}$ or bylaws ${ }^{32}$ to contain restrictions on the transfer of shares. And at all times the law enabled the corporation to amend the articles "to add to ... or otherwise alter the provisions thereof in any respect consistent with the law under which the corporation exists ..." 33 and generally to amend the bylaws. ${ }^{34}$

In 1960 and 1961 the majority (fifty-four per cent) shareholder (Mr. Russo) amended the bylaws by inserting transfer restrictions. Thereafter, any shareholder who wislied to sell to an outsider was required first to offer his shares at the same price and on the same terms to the other shareholders and the corporation. ${ }^{35}$ Mrs. Ashkins, who owned thirty-nine per cent of the outstanding common shares, ${ }^{36}$ granted an option to purchase her shares to an outsider. ${ }^{37}$ Thereupon Mr. Russo sought a declara-

\footnotetext{
2961 Cal. 2d 283, 391 P.2d 828, 38 Cal. Rptr. 348 (1964).

30 Id. at 284, 391 P.2d at 829,38 Cal. Rptr. at 348.

31 CaL. CORP. CODE $\$ 305$.

32 CAL. CORP. CODE $\& 501(\mathrm{~g})$.

33 CAI. CORP. CODE $\$ 3602$ (b).

34 CAL. CORP. CODE $\$ 500$.

3561 Cal. 2d at 284-85, 391 P.2d at 829, 38 Cal. Rptr. at 349. The bylaws were chosen for amendment probably because the majority shareholder was thus able to make the amendment simply by obtaining written assent of shareholders entitled to exercise a majority of the voting power of the corporation. CAL. CORP. CODE $\$ 500$. Compare the requirements for amendment to the articles. E.g., CAT. CORP. CoDE $\$ \S 2239,3632,3634-35$.

${ }^{38}$ The remaining seven per cent were owned by a third shareholder, Adeline Israel. Lower court opinion, Tu-Vu Drive-In Corp. v. Ashkins, 34 Cal. Rptr. 622 (1963) (vacated).

37 Evidently Mrs. Ashkins was unaware of the bylaw amendinent when she granted the option to the outsider, Sero Amusement Company. In fact, no actual notice of the bylaw amendment was given to the defendant minority shareholder until a later time. During oral
} 
tory judgment sustaining the validity of the bylaw transfer restrictions. The bylaw transfer restriction, as applied to Mrs. Ashkins' shares, was held invalid by the district court of appeal on three grounds. ${ }^{38}$ The court first used a property law approach. Mrs. Ashkins could not be deprived of her "vested right to retain her shares free from any restrictions on transfer other than those imposed when the shares were originally issued. ${ }^{\prime 39}$ Second, the court held that a share of stock comprises a contract which includes the bylaws existing when the shares were issued. Mrs. Ashkins' rights under her contract with the corporation could not be altered without her consent. ${ }^{40}$ Finally, the court, paraphrasing section $501(\mathrm{~g})$ of the California Corporations Code, ${ }^{41}$ said that bylaws restricting share transfers must be reasonable and operate equally on all persons of the same class. Retroactive operation of the bylaw transfer restrictions, the court inplied, would operate unequally. ${ }^{42}$ Bylaws should therefore be construed as prospective whenever possible. Insofar as they are retroactive and thereby impair an existing obligation of the corporation, they are

argument of the case in the California Supreme Court, some attention was given to the question whether such a procedure constitutes a denial of due process to nonparticipating sharcholders (Reporter's Transcript of Oral Argument, pp. 4, 12, 15), but that issue was not treated in the court's opinion.

3834 Cal. Rptr. 622, 622-25 (1963) (vacated). That Mrs. Ashkins was ignorant of the transfer restrictions was mentioned but not emphasized as a reason for decision.

$30 \mathrm{Id}$. at 623. (Emphasis added.)

$40 \mathrm{Id}$. at 623-24, citing the discussion in Casady v. Modern Metal Mfg. Co., $188 \mathrm{Cal}$ App. 2d 728, 733, $10 \mathrm{Cal}$. Rptr. 790, 793 (1962). This approach is no more helpful than the preceding vested rights argument. It is either nothing more than question-begging or it is illogical under prevailing doctrine, since the bylaw "contract" incorporated the Corporations Code and its provisions for bylaw amendment. The "contract" therefore provided for amendment in exactly the manner followed by the majority shareholder in $T u-V u$.

41 CAL. CORP. CODE $\$ 501(\mathrm{~g})$. This section speaks of "reasonable restrictions upon the right to transfer or hypothecate shares." The reasonableness there required probably concerns mainly the terms of the restriction, its "absoluteness" rather than its retroactive effect, and its application to outstanding shares. However, the language of the supreme court's opinion in Tu-Vu suggests to the contrary. See 61 Cal. 2 d at 286, 391 P.2d at 830, 38 Cal. Rptr. at 350.

$4234 \mathrm{Cal}$. Rptr. at 624 . The court cited at this point in the opinion Lindsay-Strathmore Irr. Dist. v. Wutchumna Water Co., 111 Cal. App. 688, 701, 296 Pac. 933 (1931). That case held imvalid a water company's resolution, passed after shares of stock had been issued to an irrigation district, providing that no water should be used on land outside the watershed of the rivers from which the water was taken except where water had previously been used on such lands. The court concluded that the resolution arbitrarily discriminated between different shareholders and deprived the district of the proportion of water to which it was entitled by virtue of its ownership of stock which had been purchased in reliance on the articles, bylaws and conditions then existing. Whatever the appeal of the decision in LindsayStrathmore, the resolution there operated nnequally in a way not evident in $T u$-V $u$ where all outstanding shares were ostensibly treated alike. Nevertheless, the general prohibition against discriminatory effects of corporate resolutions in Lindsay-Strathmore seems sound and may have soine applicability to the $T u$-Vu problein. See text accompanying note 153 infra. 
unreasonable and illegal..$^{43}$ That this amounted to an intertemporal choice of law is-apparent when the court's decision is viewed as holding that the law of free transferability, which was applicable to the shares when they were issued, would continue to apply to those shares-it could not be changed by the majority.

The decision of the district court of appeal, which hardly came to grips with relevant policy or doctrinal considerations, was reversed by the Supreme Court of California. ${ }^{44}$ The supreme court held that the corporation could enforce a new bylaw against a nonconsenting shareholder who acquired his shares prior to the amendment.

The supreme court found only two questions relevant: First, did the statute authorize adoption of the bylaw; and second, did that bylaw unconstitutionally impair Mrs. Ashkins' contract with the corporation? The court regarded both as questions of the reasonableness of the bylaw and adopted a balancing approach. ${ }^{45}$ The extent of the impairment of the complaining shareholder's rights was weighed against the legitimate interests to be furthered by the bylaw. Surprisingly, Mrs. Ashkins' asserted right was found "innocuous and insubstantial" because the transfer restriction 'merely proscribes Ashkins' choice of transferees while insuring her the price and terms equal to those offered by the outsider."140 Apparently the court failed to recognize that the price and terms she

43 For this proposition the court cited People ex rel. Bosqui v. Crockett, $9 \mathrm{Cal} .112,114$ (1858), where a bylaw passed two days after a transfer was held inoperative with respect to that transfer. Obviously, $T u-V u$ did not involve retroactivity of this kind. See text accompanying notes 144-46 infra.

Crockett, like $T u-V u$, also involved the question whether a purchaser of stock is bound by transfer restrictions of which he had neither knowledge nor notice at the time of transfer. Both courts answered this question in the negative. See CaL. CoRp. COde $\S 2404$; CaL. ComeM. CODE $\$ 8204$.

44 Tu-Vu Drive-In Corp. v. Ashkins, 61 Cal. 2d 283, 391 P.2d 828, 38 Cal. Rptr. 348 (1964).

45 The statutory question involved construing the phrase authorizing "reasonable restrictions upon the right to transfer or hypothecate shares." Cax. CORP. CODE $\$ 501$ (g).

4061 Cal. 2d at 287, 391 P.2d at 830, 38 Cal. Rptr. at 350. The court quickly disposed of the contract argument by reference to the reserved power of the state. This reserved power forms part of every shareholder's contract with the corporation; the corporation, in turn, is derivatively enpowered to alter its contract with the shareholder. $61 \mathrm{Cal} .2 \mathrm{~d}$ at 288, 391 P.2d at 831, $38 \mathrm{Cal}$. Rptr. at 351. In California, reserved power clauses can be found in $\S 1$, article XII, of the constitution and in $\S 126$ of the Corporations Code together with the aunendment sections, CAX. CORP. CODE $\$ \S 500,3600-02$. California also bas a general reserved power clause going beyond the field of corporation law, but preserving "vested rights." CAx. Gov's CODE § 9606. The court also relied on California cases which, it said, sustained bylaws curtailing far more substantial rights than those at stake in the Tu-Vu case. $61 \mathrm{Cal}$. 2d at 287, 391 P.2d at 830, 38 Cal. Rptr. at 350. The court cited a number of cases involving bylaw aunendments which retroactively removed restrictions on ahenation, abrogated voting powers, or made other, less important changes in shares. Included was a case upholding an assessment on shares held by a nonconsenting holder who purchased his shares prior to passage of the article authorizing the assessment, Wilson v. Cherokee Drift Mining Co., 14 Cal. 2d 56, 92 P.2d 802 (1939). 
could obtain from an outsider after her shares had been subjected to the bylaw restrictions would in all probability be less advantageous than those she might have obtained before. ${ }^{47}$

In amending the bylaws, the majority shareholder in $T u-V u$ was acting as lawmaker for the corporation. His exercise of voting power had an impact on present and potential shareholders similar to that of a legislative change or judicial decision pertinent to the corporation. The new bylaw operated prospectively in that it applied only to transfers after its adoption. But the new bylaw had an impact on Mrs. Ashkins' prior investment in Tu-Vu common stock at a time when those shares could be resold without restriction.

The $T u$-Vu opinion has been strongly criticized for its misuse of case law and statutory authority.8.$^{48}$ Moreover, in not openly discussing the validity of bylaw amendments in terms of retroactivity, ${ }^{49}$ the opinion evades the intertemporal law problem present in the case.

The complex of retroactivity, reliance and investment value issues involved in a case like $T u$-Vu traditionally has been approached by using a set of questionable constitutional rules accompanied and finally succeeded by a mechanical doctrime of vested rights. ${ }^{50}$ Both approaches have generally been superseded by ainorphous and usually impotent rules of fairness and reasonableness and by a variety of partial safeguards. ${ }^{51}$ Analysis of the traditional approaches and a newer equitable approach, as well as of their deficiencies, will precede an exploration of some relevant factors which should enter into the intertemporal choice of law but which have too often been lost in a sea of conclusory assertions.

\section{B. Traditional Concepts in Intertemporal Corporation Law}

\section{Constitutional Limitations on Retroactivity}

The Cahifornia Supreme Court implicitly began its reasoning in $T u-V u$ by using the first major doctrine employed in the United States to govern

47 The number of interested purchasers and the price they would be willing to pay would be drastically reduced since their offers would go for naught if the corporation or other shareholders chose to exercise the first option. And even in the unlikely event that the corporation and other shareholders allowed Mrs. Ashkins to sell her shares, the shares presumably would be subject to transfer restrictions in the hands of the transferee and therefore less valuable to him than free stock. Moreover, the terms on whieh Mrs. Ashkins could negotiate with an outsider would be influenced by the fact that the Tu-Vu Corporation or its other shareholders might become substituted as the purchasers and might present less reliable sources of payment (if installments were contemplated).

48 See Note, 53 CarrF. L. REv. 692, 694-97 (1965); Counment, 17 Hastangs L.J. 583, 588-90 (1966).

40 The court's questions during oral argument somewhat more openly suggest the temporal sequence of events and the retroactivity problem. See, e.g., Reporters's Transcript of Oral Argument, pp. 15-16.

50 See text accompanying notes 52-81 infra.

51 See text accompanying notes 82-108 infra. 
changes in corporation law: the proposition in Dartmouth College $e^{52}$ that a corporate charter is a "contract" within the meaning of the contract clause in the tenth section of article I of the United States Constitution. ${ }^{\text {b3 }}$ This proposition implied that the terms of a corporation's existence, as spelled out in the instrument creating the corporation, were "frozen" against change by the state. Later, when the practice of organizing corporations by special legislative act gave way to incorporation by qualification under general corporation laws, the Dartmouth College doctrine survived and the "contract" was deemed to include all the corporation laws of the state on the date of incorporation. ${ }^{54}$

The Dartmouth College rule together with the concept that the contract comprises the entire corporation law of the incorporating state at the time of formation would, if taken hiterally and applied resolutely, lead to remarkable and intolerable consequences. If every charter were an

\footnotetext{
52 Trustees of Dartmouth College v. Woodward, 17 U.S. (4 Wheat.) 518 (1819).

53 See generally Hale, The Supreme Court and the Contract Clause, 57 Harv. L. REv. 512 (1944).

If the contract clause applies only to legislatures and not to courts, as Tidal Oil Co. v. Flanagan, 263 U.S. 444 (1924) held, and only to state legislatures, not Congress, and assuming it is the only apphicable constitutional barrier, nothing of constitutional stature prevents the courts from applying overruling decisions retroactively to contracts made on the basis of judicial decisions in effect when the contract was made. See generally Annot., 14 L. Ed. $2 d$ 992 (1966).

The process of reasoning involved in the Dartmouth College case is the familiar one of classifying legal concepts, institutions or relations, a process known in territorial conflict of laws literature as "characterization," "quahification," "classification" or "interpretation." Although characterization is a necessary part of much legal reasoming and sometimes a useful shortcut when used descriptively in analyzing a legal problem, it can often narrow the process. The contract clause has given rise to its fair share of "characterization" problems. See, e.g., Maynard v. Hill, 125 U.S. 190 (1888) ; Lindsay-Strathmore Irr. Dist. v. Wutchumna Water Co., 111 Cal. App. 688, 926 Pac. 933 (1931).

54 See authorities cited in notes 56,63 and 65 infra. See also Peters v. United States Mortgage Co., 13 Del. Ch. 11, 114 Atl. 598 (Ch. 1921).

The early practice of special legislative charters has now been superseded by general corporation laws. Compliance with these laws enables incorporators to obtain a charter without individualized legislative action. In unany states, special charters are forbidden by the state constitution. See, e.g., CAIIF. Const. art. XII, \& 1. Consequently, the amendment process has changed. Formerly, if a charter had been specially issued by the state, it could be amended only by separate legislation. Charters obtained under a general corporation law may be amended either by legislative amendment of portions of that law or by action of tho corporation in accordance with enabling sections of that law.

The artificial classification of (special legislative) charters as contracts in Dartmouth College becaune even more questionable when it was applied to corporate charters formed under general corporation laws. Nevertheless, it is still accepted doctrine that a charter comprises a contract between the state and the corporation, as well as between the corporation and its members or among the inembers theunselves. See, e.g., State ex rel. Starkey v. Alaslea Airlines, Inc., 68 Wash. 2d 297, 413 P.2d 352 (1966). Morcover, since the terms of that contract are deemed to include the general corporation law of the state, the reserved power clause of the state constitution or statute is also part of the contract. See, e.g., Germer v. Triple-State Natural Gas \& Oll, 60 W. Va. 143, 54 S.E. 509 (1906).
} 
immutable contract, the regulatory power of the government over corporations would be substantially disarmed. ${ }^{55}$ Moreover, the state's power to regulate would differ according to the terms of the charter of each corporation; these terms would, in turn, vary with the time each charter was issued. Each corporation formed under general laws would carry all its hife the cliaracteristics, powers and limits imposed by the general corporation law in effect when it was formed. ${ }^{56}$ The state would thereby be prevented from legislatimg with respect to all corporations within its reach as a class. Furthermore, inasmuch as the corporate charter or articles, together with the included state corporation law, had also been held to form a contract both between the corporation and its shareholders and among the shareholders themselves, ${ }^{57}$ no change in purposes, powers, structure, management or finance would be possible except when the sliareholders unanimously agreed to amend these contracts. ${ }^{58}$ The state could not enact new laws enabling majority shareholders to change the internal corporate rules in breach of their "contract." A minority shareholder would be well protected against the kind of change in the internal law of the organization whicl befell Mrs. Ashkins. By the same token, however, the majority would be unable to implement even the most desirable change over the dissent of a minority shareholder, whether lie acted in misguided good faith or to extort a price from his fellow investors. In short, it is very clear that the Dartmouth College principles were entirely unrealistic and unworkable in an economy heavily dependent on corporate imvestment.

55 But see Schramn v. Bank of California, 143 Ore. 546, 20 P.2d 1093 (1933) (holding that even apart from a reserved power clause, a corporate charter yields to the police power of the state). See also Stone v. Mississippi, 101 U.S. 814 (1880) (holding that a state does not surrender its police power in granting a lottery monopoly even if the monopoly be viewed as a contract).

56 Perhaps other contemporaneous laws having some pertinence to the existence and qualities of the corporation would also be read into the charter-contract and frozen there. See 1 Thosirson, Corporations § 332 (3d ed. 1927); Lynch, Majority's Power to Effect Fundamental Changes in Shareholder Rights, 2 Corp. Prac. Comm., No. 4, pp. 1, 3 \& n.5 (1961). "There is impledly written into every corporate charter in this state, as a constituent part thereof, every pertinent provision of our Constitution and statutes." Morris v. American Pub. Util. Co., 14 Del. Ch. 136, 145, 122 Atl. 696, 701 (Ch. 1923). The doctrine of incorporating contemporaneous law conflicts in some ways with the purpose of the reserved power clause. But the conceptual conflict has not proved troublesome. Perhaps because the reserved power clause is read into the charter, the charter's incorporation of statutory law is taken to be an incorporation of that law as it may change from time to time. This mounts to a decision to choose the latest law in effect as forming part of the charter as well as choosing it to regulate the corporation as an external matter.

57 See, e.g., Avondale Land Co. v. Shook, 170 Ala. 379, 54 So. 268 (1911); Zabriskie v. Hackensack \& N.Y.R.R., 18 N.J. Eq. 178 (1867); Wheatley v. A. I. Root Co., 147 Ohio St. 127, 69 N.E.2d 187 (1946) ; Garey v. St. Joe Mining Co., 32 Utah 497, 91 Pac. 369 (1907).

58 Unless, of course, a power of amendment had been reserved to the majority in the original articles or statutory "contract." 
Fortunately, the case that created these problems also offered a solution. Justice Story's concurring opinion in Dartmouth College mentioned that a state could change the terms of the charter contract if it had reserved that power when the contract was formed. ${ }^{59}$ Reservation of such power was quite simple. When a legislative charter was issued, it was drafted to contaim a clause expressly reserving the power on the part of one of the contracting parties (the state) unilaterally to change the contract. After Dartmouth College, nearly all legislative charters included such a reserved power clause; when general corporation laws were enacted, they (or the state constitutions) contained similar reservations of power to amend or repeal the law and thus the corporation's contract with the state. ${ }^{60}$ Therefore, although Dartmouth College erred, the error was easily remedied, at least as to corporations formed thereafter. ${ }^{61}$

Corporations formed prior to routine inclusion of the reserved power clause were governed by the Dartmouth College principles; ${ }^{22}$ those formed thereafter were governed by some version of the reserved power concept. Whether that reserved power eliminated all the implications of Dartmouth College - for example, whether it permitted not only cliarter amendments by state legislation but also by less than unanimous shareholder action-lias not been uniformly answered. ${ }^{33}$

59 The suggestion of reserving a power to the legislature lad been made earlier by the Supreme Judicial Court of Massachusetts in Wales v. Stetson, 2 Mass. 143 (1806). See Greenwood v. Union Freight Co., 105 U.S. 13 (1882).

80 Of the fifty states, only Louisiana does not have an express reserved power clause in constitution or statute. Note, 15 S.C.L. REv. 506, 507 (1963). For an historical study of the California reserved power clause in article XII, § 1 , of the Cabfornia Constitution, sce McNutry, Backgrodnd Study, Cazifornta Constitution articte XII Corporations and Public Utritres 8-28 (1966) (printed by Calif. Const. Rev. Comm.).

61 For arguments that Dartmouth College drastically misconceived the problem, see, e.g., Batcantine, Corporations 645-46 (1946); Stevens, Corporattons \& 21 (1936); Dodd, Dissenting Shareholders and Amendments to Corporate Charters, 75 U. PA. L. REv. 585, 593 (1927); address by Aldace F. Walker, President of the Vermont Bar Association, entitled "A Legal Muminy or the Present Status of the Dartmouth College Case," reprinted from the proceedings of the Vermont Bar Association (1886).

62 See Dodge v. Woolsey, 59 U.S. 331 (1855); State ex rel. Starkey v. Alaska Airlines, Inc., 68 Wash. 2d 297, 413 P.2d 352 (1966); Note, 15 S.C.L. REv. 506 (1963). Some cases seen to have taken the position that the charters of even pre-reserved power clause corporations niay he aniended by legislative or majority shareholder action so long as the change is not suhstantial. See cases cited by Lynch, supra note 56, at pp. 12-18; Note, 54 HARv. L. Rev. 1368 (1941).

63 The reserved power concept has received different interpretations at different times and in different jurisdictions. See generally Dodd, Amendment of Corporate Articles inder the New Ohio General Corporation Act, 4 U. Cnvc. L. Rev. 129 (1930); Gibson, How Fixed Are Class Shareholder Rights, 23 LAw \& ConTEMr. Prob. 238 (1958); Hayes, Extent of the Legislature's Reserve Power to Change Common Law Attributes of Corporations, 13 VAND. L. REv. 261 (1959); Lattin, Minority and Dissenting Shareholders' Rights in Fundamental Changes, 23 LAW \& Contearp. PROB. 30 ' (1958); Lynch, supra note 56; Note, 55 CoLvar. L. Rev. 414 (1955) ; Note, 29 Cortum. L. Rev. 88 (1929); Note, 15 S.C.L. Rev. 506 (1963); Note, 77 U. PA. L. REV. 256 (1928). 
In some states, the reserved power clause is thought to apply only to the charter viewed as a contract between a corporation and the state, and not $\mathrm{m}$ its capacity as a contract between a corporation and its shareholders or among the shareholders. ${ }^{04}$ One result of this narrow interpretation is to allow the state to amend the corporation law in ways which alter the rules governing the corporation, but to preclude majority shareholders or directors from using an enabling statute to enact new rules governing the corporation if a dissenting shareholder raises the charter contract as a barrier to such change. In a jurisdiction taking this view, a majority may change the legal rules applicable to relationships between the shareholders and the corporation or among the shareholders themselves prospectively only. The new rules can then apply only to shares issued after the date of the charter amendment. Hence, the future exercise of rights of previously issued shares may not be altered by majority action dependent on amendments of the bylaws or articles after the dissenter's stock was issued, ${ }^{65}$ although the same result could be accomplished by a compulsory legislative revision of the state corporation law.

64 See cases collected in Lynch, supra note 56, at p. 6, n.11, pp. 15-22. New Jersey and Utah were the leading exemplars of the narrow interpretation of state corporate reserved power clauses. See, e.g., Zabriskie v. Hackensack \& N.Y.R.R., 18 N.J. Eq. 178 (Ch. 1867); In re Collins-Doan Co., 1 N.J. Super. 441, 61 A.2d 913 (1948), rev'd, 4 N.J. Super. 385, 67 A.2d 353, rev'd, 3 N.J. 382, 70 A.2d 159 (1949); Garey v. St. Joe Mining Co., 32 Utah 497, 91 Pac. 369 (1907). Some other states took the same approach. See, e.g., Wheatley v. A. I. Root Co., 147 Ohio St. 127, 69 N.E.2d 187 (1946); Yukon Mill \& Grain Co. v. Vose, 201 Okla. 376, 206 P.2d 206 (1949); State ex rel. Swanson v. Perham, 30 Wash. 2d 368, 191 P.2d 689 (1948). Cf. Ohio State Life Ins. Co. v. Clark, 274 F.2d 771 (6th Cir. 1960); Westlake Hospital Ass'n v. Blix, 13 III. 2d 183, 148 N.E.2d 471 (1958); 2 COOK, CoRPORATIONS $\S 501$ (8th ed. 1923); 1 THOMPSON, CoRPORArions $\S 434$ (3d ed. 1927). See also Jacobson v. Bachman, 16 Utah 2d 356, 401 P.2d 181 (1965).

65 Some cases seem to treat the date the corporation was formed as the bench mark date for determining whether amendments antedate or follow the contract or formation of vested rights, perhaps on the assumption that the time of formation was the time the dissenting shareholders acquired their shares or that the dissenters stand in the shoes of the original investors. See, e.g., Faunce v. Boost Co., 15 N.J. Super. 534, 83 A.2d 649 (1951); Albrecht, Maguire \& Co. v. General Plastics, Inc., 256 App. Div. 134, 9 N.Y.S.2d 415, aff'd, 280 N.Y. 840, 21 N.E.2d 887 (1939); Sandor Petroleum v. Williains, 321 S.W.2d 614 (Tex. Civ. App. 1959). Others specifically refer to the law in effect at the time a dissenting shareholder purchased his shares as the law embodied in his shareholder contract. See, e.g., Keller v. Wilson, 21 Del. Ch. 391, 190 Atl. 115 (1936); Kreiker v. Naylor Pipe Co., 374 I11. 364, 29 N.E.2d 502 (1940) ; Schaffner v. Standard Boiler \& Plate Iron Co., 150 Ohio St. 454, 460, 83 N.E.2d 192, 195 (1948); Milwaukee Sanitarium v. Lynch, 238 Wis. 628, 300 N.W. 760 (1941). See Latrin, Corporations 502 n.21 (1959); Lynch, supra note 56, at pp. 17-18. If the contract analysis is to be used, the law in effect at the time a sharcholder invests should be chosen as the law embodied in his contract. Otherwise he will be burdened with ascertaining, at his peril, the law in effect when the corporation was imcorporated. A shareholder's intertemporal objection was defeated in Detroit \& Canada Tunnel Corp. v. Martin, 353 Mich. 219, 91 N.W.2d 525 (1958), because the law existing at the time of his investment allowed the contested amendment, although the law at the time of incorporation did not.

Choosing the law in effect at the time of investment might require differentiation between a sharcholder who purchased his stock directly from the corporation and one who 
Almost all states have now adopted a broader view of reserved power clauses. ${ }^{66}$ With respect to the contract clause, legislation may change the rights of holders of shares outstanding at the time of enactment; and it can also authorize majority shareholders to impose new institutional rules on minority holders of outstanding shares. ${ }^{67}$ For example, if the legislature annended the section which formerly made cumulative voting mandatory to allow waiver of cumulative voting by provision in the articles, a statutory majority of shareholders could thereafter amend the articles to provide for straight voting over the protest of a minority shareholder who purchased his stock before the statutory amendment. ${ }^{68}$ One somewhat

purchased from another shareholder. A purchaser from the corporation would be governed by the law in effect when he first invested, and a transferce would be governed by the law in effect when his transferor invested. This distinction in effect views the current law as inhering in the shares from their original issue until their cancellation (or reacquisition and resale by the corporation). It would not only require a transferee to ascertain when his transferor's shares had first heen issued, but would differentiate among a single holder's shares if he acquired them from more than one transferor. For these reasons a New Jersey court in Allen v. Francisco Sugar Co., 92 N.J. Eq. 431, 112 Atl. 887 (1921), rejected the time of investment approach in favor of the time when the corporation was formed.

Much could be said for governing each shareholder by the law in effect when be bought his shares, whether he acquired them from the corporation or from a prior owner. Cf. Lynch, supra note 56, at p. 17 n.44. However, this theory also would necessitate differentiating among shares owned by one holder according to their date of acquisition, an unattractive necessity. The choice of law current at the time of incorporation would be far sinpler, although burdensome on the investor and especially difficult to handle by a conscious contract rationale.

${ }^{66}$ See Lynch, supra note 56, at pp. 8-9.

67 For summaries of this view and collections of cases, see LATrin \& Jennings, Cases oN Corporations 1305-06 (1959); Dodd, Amendment of Corporate Articles under the New Olio General Act, 4 U. C.Nc. L. REv. 129 (1930); Dodd, Dissenting shareholders and Amendments to Corporate Charters, 75 U. PA. L. Rev. 585, 723 (1927); Gibson, How Fixed Are Class Shareholder Rights, 23 LAw \& CoNTEMr. ProB. 283 (1958); Hayes, Extent of the Legislature's Reserve Power to Change Common Law Altributes of Corporations, 13 VAND. L. REv. 261 (1959); Lattin, A Primer on Fundamental Corporate Changes, 1 W. Res. L. Rev. 3 (1949); Lynch, supra note 56; Stern, The Limitations of the Power of a State under a Reserved Right to Amend or Repeal Charters of Incorporation, 53 U. PA. L. REv. 1 (1905); Note, 37 CoRNeII L.Q. 768 (1952); Note, 15 S.C.L. REv. 506 (1963).

In California, as to amendinent of articles, see Wilson v. Cherokee Drift Mining Co., 14 Cal. 2d 56, 92 P.2d 802 (1939); Silva v. Coastal Plywood \& Timber Co., 124 Cal. App. 2d 276, 268 P.2d 510 (1954); Heller Inv. Co. v. Southern Title \& Trust Co., 17 Cal. App. 2d 202, 61 P.2d 807 (1936); Loney v. Consolidated Water Co., 122 Cal. App. 350, 9 P.2d 888 (1932); Farbstein v. Pacific Oil Tool Co., 127 Cal. App. 157, 15 P.2d 766 (1932). As to bylaw amendinents, see Tu-Vu Drive-In Corp. v. Ashkins, 61 Cal. 2d 283, 391 P.2d 828, 38 Cal. Rptr. 348 (1964), and cases cited therein. Butt see Bornstein v. District Grand Lodge No. 4, 2 Cal. App. 624, 84 Pac. 271 (1906) (vested rights and unreasonable bylaw impairment of contract rights).

68 Cf. State ex rel. Starkey v. Alaska Airlines, Inc., 68 Wash. 2d 297, 413 P.2d 352 (1966). To exaggerate the intertemporal conflict, it may be hypothesized that all the shareholders making up the majority bought their shares after the statute was annended and all the dissenters had purchased their shares before the amendenent. In such a case, the retroactivity aspect of the amendment would give rise to strong arguments of reliance and unfairness. 
elaborate means of rationalizing this result has been as follows: (1) the state, under its reserved power to repeal the charter, can, by threatening repeal, condition the continued existence of the corporation upon acceptance of new voting rules; (2) since the state can compel the corporation to accede to a change in its articles, the state can condition the continued existence of the corporation on acceptance of a new rule permitting a statutory majority to change from cumulative to straight voting over the dissent of a holder of shares outstanding at the time of the amendment; therefore, (3) action by a statutory majority to amend the articles from cumulative to straight voting is not invalid under the contract clause. ${ }^{69}$ Thus, the authority of the reserved power clause in effect has been delegated by permissive legislation to the majority shareholders. This use of the reserved power clause neutrahizes all contract clause objections and at least subinerges other himitations on legislative or shareholders intertemporal choices of corporate law. ${ }^{70}$ At the same time, however, this

69 "It is well settled that any change or alteration the Legislature might make by direct act may be made by delegating to the corporation, or a majority or some other percentage of its stockholders, the power to do so." Breslav v. New York \& Queens Elec. Light \& Power Co., 249 App. Div. 181, 184, 291 N.Y. Supp. 932, 936 (1936), aff'd, 273 N.Y. 593, 7 N.E.2d 708 (1937). See Mobile Press Register v. McGowin, 271 Ala. 414, 124 So. 2d 812 (1960) ; Somerville v. St. Louis Mining \& Mill. Co., 46 Mont. 268, 127 Pac. 464 (1912); State ex rel. Holekainp v. Holekamp Lumber, 331 S.W.2d 171 (Mo. 1960) (reserve power lacking); Drew v. Beckwith, Quinn \& Co., 57 Wyo. 140, 114 P.2d 98 (1941). The notion that the power to do the greater necessarily imcludes power to do the lesser apparently underlies most of the recent cases upholding charter amendinents over the objection of holders of shares outstanding when the amendunent was made or of shares outstanding when a change in law necessary to the amendinent took effect. See, e.g., (a) pre-emptive rights, Gottlieb v. Heyden Chem Corp., 33 Del. Ch. 82, 90 A.2d 660, aff'd, 33 Del. Ch. 283, 92 A.2d 594 (Sup. Ct. 1952); Milwaukee Sanitariunı v. Lynch, 238 Wis. 628, 300 N.W. 760 (1941); (b) voting rights, Looker v. Maynard, 179 U.S. 46 (1900) ; Miller v. State, 82 U.S. (15 Wall.) 478 (1872); Gregg v. Granby Mining \& Smelting Co., 164 Mo. 616, 65 S.W. 312 (1901); Metzger v. George Washington Memorial Park, Inc., 380 Pa. 350, 110 A.2d 425 (1955); Quilliam v. Hebbronville Util., Inc., 241 S.W.2d 225 (Tex. Civ. App. 195I); (c) restrictions on transfer, Tu-Vu Drive-In Corp. v. Ashkins, 61 Cal. 2d 283, 391 P.2d 828, 38 Cal. Rptr. 348 (1964); (d) accrued and unpaid but undeclared dividends, Hottenstem v. York Ice Mach. Corp., 136 F.2d 944 (3d Cir. 1943) ; Barrett v. Denver Tramway Corp., 53 F. Supp. 198 (D. Del. 1943), aff'd, 146 F.2d 701 (3d Cir. 1944) ; Federal United Corp. v. Havender, 24 Del. Ch. 318, 11 A.2d 331 (Sup. Ct. 1940) ; Sherman v. Pepin Pickling Co., 230 Minn. 87, 41 N.W.2d 571 (1950); McNulty v. W. \& J. Sloane, 184 Misc. 835, 54 N.Y.S.2d 253 (Sup. Ct. 1945 ).

In a few cases, a reserved power clause of sorts was contained in the articles of incorporation, apparently at the time the corporation was formed or the dissenting shareholder mvested. See, e.g., Western Airlines, Inc. v. Sobieski, 191 Cal. App. 2d 399, 12 Cal. Rptr. 719 (1961); Maddock v. Vorcione Corp., 17 Del. Ch. 39, 147 Atl. 255 (Ch. 1929). Such elauses have been mentioned, though not heavily relied on, by the courts in explaining the doctrinal basis of their decisions to uphold amendinents agaimst a vested rights claim by a dissenting shareholder.

70 See, e.g., Phillips Petroleum Co. v. Jenkins, 297 U.S. 629 (1936) ; Hartford Acc. \& Indem. Co. v. W. S. Dickey Clay Mfg. Co., 26 Del. Ch. 411, 24 A.2d 315 (Sup. Ct. 1942); Pennsylvania R.R. v. State, 15 App. Div. 2d 269, 223 N.Y.S.2d 541 (1962). If at the time the corporation was formed the apphicable state law not only contained a reserved power 
analysis makes rules of decision at a later time depend on what the law provided at an earhier time, namely, when the corporation was formed. Only if the reserved power clause was in effect at that time is the state free later to apply law enacted after formation of the corporation. Therefore, fundamental changes must be tested to some extent under the law in effect when the corporation was formed rather than that in effect when the changes are attempted. ${ }^{71}$

Beyond questions about the reasoning of Dartmouth College and the reserved power cases, ${ }^{72}$ the effect of this approach on intertemporal law in the corporation area, and in particular on the article-amending process,

clause but also a general or specific amending statute enabling fewer than all the shareholders to push through an amendment, the objections of a dissenting shareholder have been treated solely as ones of statutory construction. See In re Sharood Shoe Corp., 192 Fed. 945 (D. Minn. 1912) (citing cases construing reserved power clauses) ; Morris v. American Pub. Util. Co., 14 Del. Ch. 136, 122 Atl. 696 (Ch. 1923). Sherman v. Pepin Pickling Co., 230 Minn. 87, 41 N.W.2d 571 (1950), upheld the elimination of accrued dividends over the dissent of mimority holders of outstanding shares where a general statute permitted an amendinent to include any provision that an original certificate might contain and the section on original certificates permitted provisions to "give such preference as it deeuns best to such . . . preferred stock." Retroactive apphication of such changes has been widely countenanced and even encouraged in the name of corporate necessity. Cf. Buxbaum, Prefered Stock-Lanw and Draftsmanship, 42 CAIIF. L. REv. 243, 298-307 (1954).

Other cases have given a more restrictive reading to statutes regulating the amending power. See, e.g., Western Foundry v. Wicker, 335 IIl. App. 106, 80 N.E.2d 548 (1948) (dividend rights); cf. State ex rel. Swanson v. Perham, 30 Wash. 2d 368, 191 P.2d 689 (1948) (voting rights). The Swanson case is discussed by Kummert, The Financial Provisions of the New Washington Business Corporation Act, 41 WASH. L. REv. 207, 209-213 (1966).

71 See State ex rel. Starkey v. Alaska Airlines, Inc., 68 Wash. 2d 297, 413 P.2d 352 (1966) ; Opinion of the Justices, 237 Mass. 619, 131 N.E. 29 (1921).

72 Several questionable steps inhere in the Dartmouth College approach and in use of the reserved power clause to sweep away contract clause limitations on intertemporal lawmaking. See sources cited in note 61 supra. See also Balcantine, Corporations 645 (rev. ed. 1946); Doe, A New View of the Dartmouth College Case, 6 Harv. L. Rev. 161 (1892).

Not all cases, however, have accepted the Dartmouth College approach or reached the conclusions to which it would lead.

For cases decided in favor of the dissenting sharcholder's claim based, at least in part, on the interteinporal sequence of events, see, e.g., (a) pre-einptive rights: Faunce v. Boost \& Co., 15 N.J. Super. 534, 83 A.2d 649 (1951); Albrecht, Maguire \& Co. v. General Plastics, Inc., 280 N.Y. 840, 21 N.E.2d 887 (1939); (b) voting: Smith v. Atchison, T. \& S.F.R.R., 64 Fed. 272 (C.C.D. Kan. 1894) ; Berger v. Amana Soc'y, 250 Iowa 1060, 95 N.W.2d 909 (1959) (redeinption as it affects voting); Orr v. Bracken County, $81 \mathrm{Ky} .593$ (1884); Sensahaugh v. Polson Plywood Co., 135 Mont. 562, 342 P.2d 1064 (1959); Loewenthal v. Rubber Reclaiming Co., 52 N.J. Eq. 440, 28 Atl. 454 (1894) ; Lord v. Equitable Life Assur. Soc'y, 194 N.Y. 212, 87 N.E. 443 (1909) ; Page v. American British Mfg. Co., 129 App. Div. 346, 113 N.Y. Supp. 734 (1908); Hays v. Coininonwealth, 82 Pa. 518 (1876); (c) restrictions on transfer: Bechtold v. Coleman Realty Co., 367 Pa. 208, 79 A.2d 661 (1951); Sandor Petroleum Corp. v. Williains, 321 S.W.2d 614 (Tex. Civ. App. 1959); (d) accrued dividends: Keller v. Wilson, 21 Del. Ch. 391, 190 Atl. 115 (Sup. Ct. 1936) ; Consolidated Film Indus., Inc. v. Johnson, 22 Del. Ch. 407, 197 Atl. 489 (Sup. Ct. 1937); Wheatley v. A. I. Root Co., 147 Ohio St. 127, 69 N.E.2d 187 (1946). 
has been unfortunate. The issue these cases pose can be framed in terms of whether legal sanctions regarding voting, transfer or issuance of shares are to be governed by rules in effect when the corporation was formed, when an objecting shareholder made his investment, when the articles were amended, or when the voting, transfer or issuance rights were exercised. Cast in these terms, the question invites consideration of such obviously relevant factors as the shareholders' notice, reliance, surprise, and frustration; facility of corporate refinancing; and investment stability. By treating the articles as a contract, the traditional approach tends to channel the inquiry into breach of contract conceptions. The analysis is then confined to such technical, doctrinal issues as whether the "contract" should be read to include a clause permitting amendment, and which provisions, if not all, of the articles are part of the contract among the shareholders. ${ }^{73}$

The contract and reserved power analyses have dominated the cases on statutory change in corporation laws and shareholders riglits. To a lesser extent they have influenced problems of shareholder amendments so

${ }^{73}$ See, e.g., Lynch, supra note 56, at p. 7. Compare State ex rel. Starkey v. Alaska Airlines, Inc., 68 Wash. 2d 297, 413 P.2d 352 (1966). Some authorities have concluded that the state's power to change its corporation law, the power reserved in a reserved power clause, is bimited by the contracts clause of the United States Constitution and may not he used to destroy a vested right. See, e.g., 7 Fletcher, Cyciopedia of Corporations \& 3681 (perm. ed. 1933) ; Note, 13 U. PIrr. L. Rev. 723, 725 (1952); cf. Venner v. Chicago City Ry., 246 III. 170, 92 N.E. 643 (1912).

Other authorities have interpreted the usual reserved power clause to eliminate completely any limit imposed by the contracts clause. See, e.g., Lynch, supra, at p. 8; authorities cited in notes 70 \& 72 supra.

Some cases and commentators seem to have treated the reserved power clause as having eliminated not only any possihility of objection based on the contract clause but any constitutional objection at all. See, e.g., McNulty v. W. \& J. Sloane, 184 Misc. 835, 54 N.Y.S.2d 253 (Sup. Ct. 1945); Lynch, supra, at pp. 18-19.

The usual dictum, however, recognizes that the reserved power clause does not authorize the legislature to take property without just compensation, Chicago, M. \& St. P.R.R. v. State, 238 U.S. 491 (1915), Opinion of the Justices, 300 Mass. 607, 14 N.E.2d 468 (1938); State v. Bancroft, 148 Wis. 124, 134 N.W. 330 (1912), or to deprive corporations of life, liberty or property without due process or equal protection of the laws, Johnson v. Goodyear Mining Co., 127 Cal. 4, 59 Pac. 304 (1899); see also Shields v. Ohio, 95 U.S. 319 (1877). Other constitutional protections specifically afforded hy a state or federal constitution are not erased by the reserved power clause. See In re Tiburcio Parrott, 1 Fed. 481 (C.C.D. Cal. 1880); Hale v. Bohannon, 38 Cal. 2d 458, 241 P.2d 4 (1952); Western Union Tel. Co. v. Hopkins, 160 Cal. 106, 116 Pac. 557 (1911); Boca Mill v. Curry, 154 Cal. 326, 97 Pac. 1117 (1908). Nonetheless, subsequent law has often been applied, by virtue of the reserved power, to materially alter the shareholder's liabilities. See Wilson v. Cherokee Drift Mining Co., 14 Cal. 2d 56, 92 P.2d 802 (1939) (weakening the vitabity of Rainey v. Michel, 6 Cal. 2d 259, 57 P.2d 932 (1936)); McGowan v. McDonald, 111 Cal. 57, 43 Pac. 418 (1896); Gallois v. West End Chem. Co., 185 Cal. App. 2d 765, 8 Cal. Rptr. 596 (1960) ; Heller Inv. Co. v. Southern Title \& Trust Co., 17 Cal. App. 2d 202, 61 P.2d 807 (1936); Farbstem v. Pacific Oil Tool Co., 127 Cal. App. 157, 15 P.2d 766 (1932). 
as to treat them as derivative exercises of the state's reserved power. Another doctrine which has also influenced the shareholder amendment problem rests on the common law rule requiring unanimous consent of shareholders to effect a fundamental, as distinguished from an auxiliary or incidental, change in the corporation. ${ }^{74}$ Changes are fundamental when they alter the basic purposes or structure of the corporation, or end its existence by a sale of all its assets or by liquidation. When statutes authorizing a simple or special majority of shareholders to amend the corporate charter were first enacted, uncertainties as to the constitutionality of such laws both as applied to pre-existing and to future corporations led some courts to hold that a dissenting shareholder might demand a casl payment for his shares equal to their fair market value. ${ }^{75}$

Notwithstanding the constitutional doubts which gave rise to the unanimous consent requirement, ${ }^{76}$ reserved power clauses have freed

74 Batlantine, Corporations 643, 668 (rev. ed. 1946); Lynch, stupra note 56, at pp. 1218; Manning, Shareholder's Appraisal Remedy, 72 YALE L.J. 223, 228-29, 246-57 (1962).

By analogy to the common law of partnerships, courts reasoned that a shareholder's contract could not be fundamentally modified by his fellow investors. Although this "fundamental change doctrine" evidently arose with respect to corporations formed before the use of reserved power clauses, it influenced decisions and legislation applying to both pre- and postreserved power clause corporations. See Cathcart v. Cathcart Van \& Storage Co., 175 Ga. 196, 165 S.E. 58 (1932); Atlanta Steel Co. v. Mynahan, 138 Ga. 668, 75 S.E. 980 (1912); Lynch, supra, at pp. 12-18.

75 The leading case is Lauman v. Lebanon Valley R.R., 30 Pa. 42 (1858), in which the court gracefully supposed that the Pennsylvania Legislature had intended to grant dissenters an appraisal right in connection with a special legislative authorization of a railroad merger. The legislature soon thereafter adopted an appraisal statute as part of a general statutory authorization for railroad mergers. Subsequently, general merger statutes for other corporations imcluded appraisal rights for dissenters to prevent minorities from being able to enjoin fundamental corporate changes. Manning, sitpra note 74, at 228-29 n.20, 246 n.38. A shareholder, unhike a partner, was thought to lack any right to require indefinite continuation of the enterprise: Since a majority of shareholders could dissolve the corporation, a simple sharcholder could not veto a fundamental corporate change- he could only demand a cash payment for his shares. If the right of a majority to dissolve was not admitted, a dissenter could block a merger or similar change. See generally Frex, Morris \& Croper, CASEs oN CORPORATIONS 1069-75 (1966).

The requirement of unanimous consent or dissenters' rights may have stemmed from a presupposition that the reserved power clause did not extend to shareholder amendments and that the pure Dartmouth College principle applied. But the doctrimal language of these cases was not consistently cast in the language of the contract clause terminology, and it is difficult to see how the appraisal right would satisfy constitutional doubts based on the contract clause. A cash payment might be akin to damages for breach, but the contract clause by its ternns was desigued to preclude any breach, not to require reparations if any breach occurred. The cash payment could better be scen as an attempt to satisfy constitutional doubts based on the rule against a taking of property by the state except for public purpose without due process and just compensation. However, the ground-breaking common law dissenters' appraisal rights cases were decided before the fourteenth amendment was adopted. See, e.g., Lauman v. Lebanon Valley R.R., supra, decided in 1858.

78 Sce, e.g., Lauman v. Lebanon Valley R.R., supra note 75; cases cited note 74 sttpra. 
corporate lawmaking from most of the constitutional limits which elsewhere dominate problems of conflict of laws in time. Largely released from constitutional restrictions, intertemporal corporation law problems, such as that in $T u-V u$, are now resolved by statutory interpretation and resort to various partial safeguards against abuse of shareholder interests.

\section{The Vested Rights Doctrine}

The trial court and the district court of appeal in $T u$-Vu decided in favor of the minority shareholder, notwithstanding the California constitutional $^{77}$ and statutory ${ }^{78}$ reserved power clauses. This decision was based on the "vested right" of a nonconsenting shareliolder to transfer his shares free from any restrictions imposed after his purchase of the shares. ${ }^{79}$ The vested rights doctrine is not explicitly grounded in any constitutional restriction on legislative power. It is, rather, a flat prohibition on legislative authorization or majority shareholder adoption of a transfer restriction bylaw applicable to outstanding shares if the holder dissents.

That these lower court holdings based on the vested rights doctrine were reversed on appeal is not surprising. Such has been the fate of many vested rights holdings in corporation law and elsewhere. Just as constitutional contract clause rules of intertemporal corporation law have largely given way to nonconstitutional considerations, the doctrine of vested rights has dwindled in respectabihty and importance. Some commentators have been led to conclude that there is nothing left of the vested rights

The fourteenth amendment had not been adopted when Dartmouth College used the contract clause. Quite possibly, that opinion would have rested on the fourteenth amendment had it been in effect.

A fundamental change, such as that accomplished by a major charter amendment, bears some resemblance to a private eminent domain proceeding. See Vorenberg, Exclusiveness of the Dissenting Stockholder's Appraisal Right, 77 HARV. L. REv. 1189, 1191 (1964).

77 See CaL. Const. art. XII, \$ 1.

78 See Cal. Corp. Code $\$ 126$; Caz. Gov's Code $\S 9606$. Both the California statutory and constitutional reserved power clauses antedated the organization of $\mathrm{Tu}-\mathrm{Vu}$ Drive-In Corporation. Section 500 of the California Corporations Code, which permits amendment of bylaws by majority shareholders, was also in effect prior to incorporation of $\mathrm{Tu}-\mathrm{Vu}$ Drive-In. It could therefore not be argued that $\mathrm{Tu}-\mathrm{Vu}$ was not covered by the statute. Nor, in view of the wording of $\S 500$, could a persuasive argument have been made that the statute only authorized application of amendments to shares issued after adoption of the bylaw amendinent. Compare, e.g., James v. The Washburn Co., 326 Mass. 356, 94 N.E.2d 479 (1950), noted, 30 B.U.L. REv. 574 (1950), 37 VA. I. REv. 318 (1951). In James, the court construed a statute that provided "every corporation may . . . change . . . the classes of its capital stock subsequently to be issued and their preferences and voting power ..." to apply only to shares issued after the shareholder neeting authorizing the change.

79 See Clerk's Transcript of the Superior Court Proceedimgs, pp. 33, 34, 47, cited in Appellant's Opening Brief in the District Court of Appeal, p. 5, Tu-Vu Drive-In Corp. v. Ashkins, 34 Cal. Rptr. 622 (1963) (vacated). 
approach and that the problems here called intertemporal law are simply questions of case-by-case fairness to be evaluated by a court or an administrative agency. ${ }^{80}$

The vested rights doctrine, like the contract approach of Dartmouth College and the unanimous consent requirement, failed for two basic reasons. First, it was too effective. Attempting to prevent abuse of institutional power, the vested rights doctrine rigidly prevented many necessary changes in the institution. Second, because of its vagueness it was unpredictable and discouraged attenupts to make even those changes which might have survived the test. ${ }^{81}$ Although aimed at a legitimate concern, this overly broad doctrine could not withstand the pressures for flexibility and self-government in corporate institutions.

\section{The Reasonableness and Fairness Test}

In most jurisdictions the principal judicial doctrine for safeguarding minority shareholders' rights has beconie the rule of reasonableness and fairness. ${ }^{82}$ This rule constitutes an "equitable limitation" upon the majority's exercise of its power to amend articles or bylaws. Freed from the rigidity of the vested rights approach, a court applying the fairness test can review and weigh all the facts and circumstances in a given case. Majority shareholder action is prohibited when it breaches some duty of fair dealing or quasi-fiduciary responsibility on the part of the controlling shareholders to the corporation or to the minority shareholders. This approach has inuch to recommend it. Flexible enough to allow legitimate or needed changes in the corporate structure or rules, it seemingly can filter out those which unduly impair the reasonable reliance and expectation interests of the minority. The court is free, in other words, to permit application of later statutory law or internal corporate rules except when fairness requires the continued apphication of earlier law notwithstanding the technical validity of the change.

Fairness undoubtedly is also the core concept in the vested rights doctrine, just as it lies at the core of territorial choice-of-law cases. It is a sufficiently broad concept to encompass most considerations affecting interteniporal choice of law. The vagueness of this test however, often

80 See Lattin, Corporations 502-07 (1959); Gibson, supra note 63, at 283-95; Hayes, supra note 63, at 280-85; Lynch, supra note 56, at pp. 9-11.

Compare Cavers, The ChOICE-OF-LAW Process 75 (1965), a section entitled "Justice in the Individual Case': The Cavers Method?".

81 Cf. Amsterdam, The Void-for-Vagueness Doctrine, 109 U. PA. L. REv. 67, 75 (1960).

82 Lattin, Equitable Limitations on Statutory or Charter Powers Given to Majority Shareholders, 30 Mrce. L. REv. 645 (1932); Lattin, A Primer on Fundamental Corporate Changes, 1 W. Res. L. Rev. 3 (1949); Note, 69 HARv. L. Rev. 538 (1956). See authorities and commentaries collected in 1 Hornstenn, Corporation Law and Practice \& 363 (1959). An early classic is Berle, Corporate Powers as Powers in Trust, 44 Harv. L. REv. 1049 (1931). See also the sources cited in note 63 supra. 
invites either judicial overprotection at the expense of needed corporate change or underprotection at the expense of the minority. The fairness test can thus lead to erratic decisional law which not only makes the planning of corporate changes and legislative revision difficult, but also takes some toll in acceptance of the law by the investment community.

Despite its virtues in theory, the fairness test has failed in practice. Its principal role has been occasionally to protect minority shareholders against egregious majority expulsion or oppression-the "fraud" or "bad faith" cases. ${ }^{83}$ Time and time again, however, this test has not protected the minority from intertemporal changes in corporate rules which seriously and needlessly defeat their investment interests. ${ }^{84} \mathrm{~A}$ few cases have prevented an amendment on fairness or equitable grounds, ${ }^{85}$ but the vested rights label or statutory contruction to deny authority have more often been used for this purpose. ${ }^{86}$ In other words, the fairness test, as fairness tests are wont to do, has turned into a fraud test, a test most cases pass

83 See O'NeAI \& DeRWIN, EXPUISTON OR OPPRESSION OF BusINess Assoctates 61-98 (1961) ; cf. Berte, Studies in the Law of Corporation Finance $28-40$ (1928).

Cf. Jones v. Missouri-Edison Elec. Co., 144 Fed. 765 (8th Cir. 1906) (majority shareholders' act in attempting to eliminate accrued cumulative dividends in a merger held to constitute a fraud on the minority).

84 See, e.g., Looker v. Maynard, 179 U.S. 46 (1900); Tu-Vu Drive-In Corp. v. Ashkins, 61 Cal. 2d 283, 38 Cal. Rptr. 348, 391 P.2d 828 (1964); Gottheb v. Heyden Chem. Corp., 33 Del. Ch. 82, 90 A.2d 660, aff'd, 33 Del. Ch. 283, 92 A.2d 594 (Sup. Ct. 1952) ; Topkis v. Delaware Hardware Co., 23 Del. Ch. 125, 2 A.2d 114 (Ch. 1938); Maddock v. Vorclone Corp., 17 Del. Ch. 39, 147 Atl. 255 (Ch. 1929); Baker v. Standard Lime \& Stone Co., 203 Md. 270, 100 A.2d 822 (1953); Royal China, Inc. v. Regal China Corp., 304 N.Y. 309, 107 N.E.2d 461 (1952); Marcus v. R. H. Macy \& Co., 297 N.Y. 38, 74 N.E.2d 228 (1947); Metzger v. George Washington Memorial Park, Inc., 380 Pa. 350, 110 A.2d 425 (1955), noted in 54 MicH. L. Rev. 279 (1955); Milwaukee Sanitarium v. Swift, 238 Wis. 628, 300 N.W. 760 (1941).

Some cominentators have been led to conclude that the fairness test no longer exists in the context of corporate recapitalizations. See, e.g., Gibson, How Fixed Are Class Sharelzolder Rights?, 23 LAW \& Contenap. Prob. 283, 296 (1958).

One disadvantage of the fairness test is that the test itself is applied "retroactively" in the sense that whether the majority shareholder's amendment was unfair is not known until after the fact (except in injunction or declaratory judgment cases). While prior judicial approval of every amendment would be almost unthinkable, prior review by an administrative agency would be quite feasible. See text accompanying notes 94-100 infra.

${ }^{85}$ See, e.g., Berger v. Amana Soc'y, 250 Iowa 1060, 95 N.W.2d 909 (1959); Faunce v. Boost Co., 15 N.J. Super. 534, 83 A.2d 649 (1951); Outwater v. Pubhic Serv. Corp., 103 N.J. Eq. 461, 143 Atl. 15 (Ch. 1928), aff'd, 104 N.J. Eq. 490, 146 Atl. 916 (Ct. Err. \& App. 1929).

86 See, e.g., Yoakam v. Providence Biltmore Hotel Co., 34 F.2d 533 (D.R.I. 1929); Albrecht, Maguire \& Co. v. General Plastics, Inc., 280 N.Y. 840, 21 N.E.2d 887 (1939); In re Amexican Fibre Chair Seat Corp., 265 N.Y. 416, 193 N.E. 254 (1934); Lord v. Equitable Life Assur. Soc'y, 194 N.Y. 212, 87 N.E. 443 (1909); Jay Ronald Co. v. Marshall Mortgage Corp., 265 App. Div. 622, 40 N.Y.S. 2d 391 (1943); Loewenthal v. Rubber Reclaiming Co., 52 N.J. Eq. 440, 28 A.2d 454 (1894); Yukon Mill \& Grain Co. v. Vose, 201 Okla. 376, 296 P.2d 206 (1949); Bechtold v. Coleman Realty Co., 367 Pa. 208, 79 A.2d 661 (1951); Sandor Petroleuun Corp. v. Williams, 321 S.W.2d 614 (Tex. Civ. App. 1959); State ex rel. Swanson v. Perham, 30 Wash. 2d 368, 191 P.2d 689 (1948).

See Note, 13 U. Pitr. L. Rev. 723 (1952). 
easily. ${ }^{87}$ Absent clear badges of hard-core fraud, the courts have hesitated to overturn majority shareholder action. ${ }^{88} \mathrm{~A}$ kind of business judgment rule severely restricts the scope of the equitable limitations, and since the burden of proving the fairness of the plan is seldom placed on its proponents, only fraud or constructive fraud can win a case for the minority. ${ }^{89}$ And, of course, the fairness test, unlike the contract clause and even the vested rights doctrine, does not serve in any way to limit legislative changes in the law, as distinguished from shareholder amendments. ${ }^{.0}$

87 See e.g., Batcantine \& Sterming, CaItrornia Corporation Laws 525 (1966).

88 Delaware seems to have been particularly permissive. See Barrett v. Denver Tramway Corp., 53 F. Supp. 198 (D. Del), afj'd, 146 F.2d 701 (3d Cir. 1944); Dodd, Accrued Dividends in Delaware Corporations-From Vested Right to Mirage, 57 HaRv. L. Rev. 894 (1944); Note, 13 U. PrrT. L. Rev. 723, 728 (1952).

80 Cf. Latty, Exploration of Legislative Remedy for Prejudicial Changes in Senior Shares, 19 U. CHr. L. REv. 759 (1952) ; Note, 74 HaRv. L. REv. 1630 (1961). A comprehensive review and evaluation of the fairness test and of other protections for minority shareholders, mainly in connection with financial changes in large Corporations may be found in Note, 58 Corvac. L. REv. 1030, 1045-48 (1958). Again, see Barrett v. Denver Tramway Corp., supra note 88.

One state has given its courts explicit statutory support for applying a fairness test. Nebraska permits a preferred shareholder who will be adversely affected to seek enjoinment of a charter amendment on grounds of fraud or unfairness. The court must enjoin the amendment if its proponents fail to demonstrate a reasonable probability that the proposed amendment is fair, just and equitable to all sharcholders affected by it. NEB. REV. STAT. \$ 21-1, 162 (1962). See also ONEAI \& DERwIN, op. cit supra note 83, at 199. The authors suggest another statutory approach which would set up fact categories to create an inference of unfairness. The illustrative categories mentioned include (1) absence of a legitimate business reason for the proposed action, (2) existence of an alternative method which would not unduly prejudice the complaining shareholder or (3) primacy of the majority's selfish interest over any independent business objective. While these categories surely describe many of the instances in which majority shareholder action should be scrutinized and perhaps enjoined, sueh a statute would hardly be self-executing and at most would give the courts some moral support.

For an examination of possible statutory treatment of changes in outstanding senior shares, see Latty, supra.

00 The standard of "fairness," while supposedly comprehending any unfairness that results from intertemporal conflicts, has tended to concentrate on nontemporal factors. The time sequence and the content of prior law have been subordinated to equitable questions, such as the motive of majority shareholders, whether a squeeze-out or freeze-out had been attempted, or the presence or absence of a "corporate purpose" for the amendment. These considerations are, by their terms, not applicable to legislative or judicial changes in corporate legal rules. Whether prior law was different, whether anyone rehed on that prior law, whether any such reliance was reasonable, whether the law invited such reliance, are questions all rendered irrelevant or subordinate by the modern approaches which emphasize the power of the lawmaker to enact a change. See, e.g., McNulty v. W. \& J. Sloane, 184 Misc. 835, 54 N.Y.S.2d 253 (Sup. Ct. 1945).

A few cases, however, have apphed the fairness test as an equitable limitation on the reserved power. See, e.g., Marshall County Bank v. Wheeling Dollar Sav. \& Trust Co., 119 W. Va. 383, 193 S.E. 915 (1937). A few cases limited the reserved power to exercise for protection of the public. See, e.g., Petition of Collins-Doan Co., 3 N.J. 382, 70 A.2d 159 (1949); Ynkon Mill \& Grain Co. v. Vose, 201 Okla. 376, 206 P.2d 206 (1949). 


\section{Other Restrictions on the Temporal Scope of Corporate Law}

Decisions like the California Supreme Court's in $T u-V u$ have not purported to leave the shareholders entirely free to apply later rules to previously issued shares. Furthermore, a number of administrative and statutory safeguards have been developed to protect against extreme or inequitable consequences flowing from a change in corporate law by the controlling shareholders. Some safeguards (proxy rules, for example) relate to the way in which the change is accomplished. ${ }^{91}$ Others (such as statutory recitals of permissible amendments) ${ }^{92}$ concern the substance of the change. Still others (such as dissenters' appraisal rights) ${ }^{93}$ allow a

91 For example, fraud, misrepresentation or misleading nondisclosure in connection with the solicitation of proxies (or the shareholder vote when articles or bylaws are amended) can sometimes be remedied by administrative or private action under state law as well as under the proxy rules adopted pursuant to Securities Exchange Act $\$ 14,48$ Stat. 892 (1934), as amended, 15 U.S.C. \$ 78(1) (1964). By virtue of the 1964 amendments to the 1934 act, the federal proxy rules now extend to many unlisted corporations, far greater coverage than had previously existed. For analysis of the 1964 amendments, see Coinment, 53 CaLIF. L. REv. 1494 (1965).

An illustration of coverage of the proxy solicitation and information problem by state general corporation law is $\$ 3637$ of the California Corporations Code which requires: "In soliciting proxies authorizing the holder thereof to vote in favor of any amendment referred to in Section 3634 or 3635 , or in soliciting written consents of shareholders thereto, the corporation shall mail to each shareholder of the corporation at his address appearing on the books of the corporation, or given by him to the corporation for the purpose of notice, or if no such address appears or is given, at the place where the principal office of the corporation is located, a concise summary of the proposed amendment and the changes proposed to be effected thereby in the rights of the shareholders. However, failure to comply with this section does not invalidate the amendment." A case illustrating judicial rules on the fairness of the mechauics of a shareholder change in internal corporate law is Berger $v$. Amana Soc'y, 253 Iowa 378, 111 N.W.2d 753 (1961). See Lynch, Control and Management of Corporation, 1959 State U. Iowa Legal INsT. 14; Note, 45 Iowa L. Rev. 615 (1960).

92 See, e.g., Cat. Corp. Code \$§ 3600-04; Ded. Code ANN. tit. 8, § 242 (1953); N.Y. Bus. Corp. LAw § 801; OHto Rev. Code ANN. \$1701.69 (1964).

93 Although the appraisal right is by no means satisfactory to dissenters in every case, it not only takes some of the pressure off judicial or administrative review of article amendments but also affords the minority some bargaining leverage if the corporation cannot easily obtain or afford the cash necessary to purchase the dissenting shares. Also, the dissenter's appraisal right has the advantage of being an "automatic" right which usually arises out of easily identifiable events without a prerequisite judicial finding of "unfairness" or violation of vested rights. However, the appraisal right is not widely granted to dissenters from simple charter amendments. On the problems involved in exercising the right generally, see Maming, The Shareholder's Appraisal Remedy, 72 YarE L.J. 223 (1962). Common law dissenters' rights have not generally been granted in recent years; the statutory remedy is assuned to have pre-empted the field (although the de facto merger doctrine may represent a reeinergence of the common law right). See, e.g., Rath v. Rath Packing Co., 136 N.W.2d 410 (Iowa 1965); Applestein v. United Board \& Carton Corp., 60 N.J. Super. 333, 159 A.2d 146 (1960); Farris v. Glen Alden Corp., 393 Pa. 427, 143 A.2d 25 (1958).

Although appraisal rights cannot be regarded as a sufficient protection against oppression and unfairness in article amendments (not to mention bylaw amendments), they may be 
minority to escape from the disadvantages foreseeable in amendments whose enactment it cannot prevent.

\section{Administrative Safeguards}

Administrative safeguards offer the most realistic hope for screening out controlling shareholders' abuses of their power as private lawmakers for the corporation. ${ }^{94}$ California is the leader in use of administrative supervision, in particular with reference to charter or bylaw amendments. ${ }^{95}$ The California Corporate Securities Law gives the Corporations Commissioner jurisdiction to permit, prohibit or qualify amendments which affect, inter alia, stock transfer restrictions and voting and preeinptive rights. The Commissioner is directed to refuse a permit "if in his opinion the plan is not fair, just or equitable to all security liolders affected." ${ }^{98} \mathrm{He}$ has staff and expertise, and the system requires prior review of proposed amendments.

Although this safeguard forms the best protection against abuse of power by majority shareholders, ${ }^{97}$ it is not airtight, as the California $T u-V u$ case $^{98}$ itself demonstrates. In $T u-V u$ the majority's action was not blocked by the Commissioner of Corporations. This may have happened because the minority did not receive notice of the change nor have an opportunity to object to the Commissioner. ${ }^{99}$ Administrative screening is

desirable as a cumulative remedy. Similarly, selling out on whatever market is available is a kind of escape valve which is sometimes helpful although it often falls short of good protection for mimority interests, especially in close corporations. See notes 77-78 supra and accompanying text.

04 Cf. Reese \& Kaufman, The Law Governing Corporate Affairs, 58 CoLuMr. L. REv. 1118 (1958); Sobieski, State Bhte Sky Jurisdiction over Foreign Corporations, 14 Hastruvas L.J. 75 (1962); Note, 46 MINN. L. Rev. 785 (1962). See generally Orschel, Administrative Protection for Shareholders in California Recapitalizations, 4 STAN. L. REv. 215, 218 (1952); Small, Changes in Rights, Preferences, Privileges and Restrictions on Outstanding Securities under the California Corporate Securities Law, 14 Hastnvas L.J. 94 (1962); Note, 58 CgLom. L. REv. 1030, 1048 (1958).

95 See Schlet, State Regulation of Corporate Financial Practices: The Catrfornia ExPERtence (1962); Dahlquist, Regulation and Civil Liability tunder the Califormia Corporate Securities Act, 33 CaIIF. L. Rev. 343 (1945), 34 CaIIF. L. Rev. 344, 543, 695, (1946) ; Jennings, The Role of the States in Corporate Regulation and Investor Protection, 23 LAw \& CGNTEMr. Prob. 193 (1958).

98 Cax. Corr. Code $\$ 25510$. See also Cax. Corp. Cone $\$ 25009$, which provides that any article or bylaw amendment is to be treated as a "sale" of a "security" if it effects "any change in the rights, preferences, privileges, or restrictions on outstanding securities."

07 See SCHLET, op. cit. supra note 95; Jennings, supra note 95, at 213-20; Note, 58 CoLusr. L. REv. 1030, 1048-55 (1958); sources cited in note 101 infra. This safeguard is, however, far from perfect. See Adickes, $A$ "Closed Corporation Law" for Califormia, 54 CALIF. L. REv. 1990 (1966).

${ }_{88}$ Tu-Vu Drive-In Corp. v. Ashkins, 61 Cal. 2d 283, 391 P.2d 828, 38 Cal. Rptr. 348 (1964).

99 This deficiency in procedure should have rendered the bylaw amendment invalid.

It has been suggested that the Counmissioner might well have found that the amendment 
time-consuming and expensive in even the most innocent situations. And while quicker and cheaper than hitigation, it is not as predictable as appraisal rights.

Protection for minority shareholders is maximized when the administrative procedure operates on a permit system with broad discretion in the agency (as in Cahifornia), ${ }^{100}$ and when other remedies (such as appraisal rights or judicial review and a well-drafted statute) are also available. Under a broad "fair, just and equitable" test, the temporal scope of a new law can be considered together with the rehance and $\mathrm{m}$ vestment interests of all the shareholders. A decision tailored to the facts of each case can thus be reached. ${ }^{101}$

\section{Statutory Safeguards}

General corporation laws supply some "automatic" protections for a minority by requiring more than a simple majority vote of shareholders to authorize important article or bylaw amendments. High-vote and classvote requirements give a substantial minority some protection, if the statutes are coinprehensively drafted and cannot be suspended by an article or bylaw provision. ${ }^{102}$ For example, the thirty-nine per cent of outstanding shares held by Mrs. Ashkins in $T u-V u$ would have enabled

was not "fair, just and equitable" under $\$ 25510$ of the Corporations Code if he had considered the question. See Note, 53 CaLIF. L. REv. 692 n.3 (1965). Nevertheless, a permit was granted (see Appellant's Opening Brief in the District Court of Appeal, p. 4), which suggests either that the Coinmissioner, in his wisdom, did not find the amendment prima facie unfair under $\$ 25510$ of the Corporations Code or that such amendments can easily slip through the system.

100 In California, the definition of a "sale" is so broad that the Commissioner's jurisdiction cannot be avoided by using bylaw instead of article amendments. Althougl separate shareholder agreements, instead of bylaws or articles, might be resorted to in an effort to escape regulation (cf. 11 Ors. CAI. ATr'y GeN. 89 (1948)), such contracts would not permit amendment without the consent of all parties to whom the contract apphied. Also, a stock transfer restriction is one kind of amendment which must be noticed on the share certificates to be effective. Cax. Corp. CODE \& 2404; Cax. Conar. CODE \& 8204. The substitution of escrowed share certificates will bring the amendment before the Commissioner even if nothing else does. Foreign incorporation apparently will not enable California-based corporations to escape the Commissioner's reach in view of the decision in Western Air Lines v. Sobieski, 191 Cal. App. 2d 399, 12 Cal. Rptr. 719 (1961).

101 No other state, however, has adopted the full California approach, perhaps because of general hostility to governmental intrusion into business affairs and vague reluctance to limit the principle of majority rule in lawmaking. Referring to the pernnit requirement in California, the leading text on Califorma corporation law states, "However, it would seem that if the amendment has received the requisite shareholder vote after a fair presentation of its effect, the Commissioner should not substitute his judgment for that of the shareholders." 1 Barlantine \& Sterling, op. cit. supra note 87, at 526. See also Dahlquist, Regulation and Civil Liability under the California Corporate Securities Act, 34 CAIIF. L. REv. 695, 738 (1946).

102 See, e.g., Omo Rev. Code ANn. § 1701.71 (1964). 
her to block amendinent of the articles of incorporation in any of the situations in which the California Corporations Code requires the affirmative vote of two-thirds of the outstanding shares. ${ }^{103}$ However, as the outcome in $T u-V u$ demonstrates, there are gaps in the statutory coverageeven in a code as sophisticated as California's. Amendment of the bylaws rather than the articles was all the majority shareholder needed in $T u-V u$, and his majority interest gave him enough votes to adopt the amendment. Perhaps California should require that stock transfer restrictions (and other iniportant terms of shares) be set forth in the articles and nowhere else. But unless the statute were to require a high vote for every article and bylaw amendment or were to specify at length those amendments which require a high vote, this kind of protection for the minority cannot adequately deal with majority power and would unnecessarily limit changes in large, publicly held corporations. ${ }^{104}$

Statutory high-vote protections are subject, of course, to change by state legislative action. Statutory amendments will, at least under current doctrines, be routinely applied to shareholder votes taken thereafter. The voting laws in effect at the time of the vote, rather than those in effect at the time the corporation was formed or the shares were issued, have usually been assumed or held to be applicable. ${ }^{105}$ Therefore, to guarantee a veto indefinitely, investors in a corporation in which the allocation of power is important cannot fully rely on statutory protections existing at the time shares first are issued.

\section{Private (Corporate) Safeguards}

Corporation statutes commonly permit the corporation to require in its articles or bylaws that shareholders act by a majority higher than the statutory minimum, or that they vote by classes even though the statute does not compel class voting. ${ }^{100}$ Corporate draftsmen often include high-

103 See CAL. CORP CODE $\$ \S 3634-35$.

104 High-vote requirements seem premised on two related propositions. First is the idea that the more votes cast for a given choice, the more likely it is that the choice is "right" and proper. Therefore, to require a high vote on important questions tends to assure that if a change is made, it will be a "right" change. If a high majority cannot be persuaded to favor that change, the status quo probably is "righter" than the change would have been. This proposition similarly underlies the requirements of high votes for amendment of state and federal constitutions. Second, a possible presupposition is that if a choice receives a high vote of affected electors, that choice should be effectuated whether "right" or not with respect to the majority or the minority. Even though we recognize that the majority may sometimes be "wrong" and so are unwilling to give a simple majority unlimited sway, a higher majority is not only less likely to be "wrong" but also deserves to determine its own destiny.

105 See, e.g., Maddock v. Vorclone Corp., 17 Del. Ch. 39, 147 Atl. 255 (Ch. 1929);

Quilliam v. Hebbronville Util., Inc., 241 S.W.2d 225 (Tex. Civ. App. 1951).

106 See, e.g., Cat. Corp. Code $§ 3632$; Des. Code ANN. tit. 8, § 102 (b) (4) (1953); N.Y. Buss. Corp. Law § 616; OHIo Rev. CODE ANN. $\$ 1701.71$ (1964). 
vote or class-vote requirements in the original articles and bylaws of closely held corporations, if the applicable statute does not impose vote requirements of sufficient magnitude or coverage to provide the desired balance of power.

Rarely are majority or class voting rules set forth in corporate articles to repeat the same requirements which contemporary law contains. Bylaws, however, sometimes restate the current statute simply to provide corporate officers with an easy source of reference to mandatory legal rules. High-vote or class-vote clauses which merely restate the current statutes can serve another generally unrecognized function that should commend them to closely held corporations. High-vote requirements in the corporate documents survive a legislative change in the statutory vote provisions, so long as the changed statute allows at least pre-existing corporations to mamtain a higher vote requirement in their individual structures. Thus ligh-vote clauses which only repeat the current statutory requirements serve as private choice-of-law (in time) clauses much as boiler-plate cloice of law (in space) clauses do when included in contracts. ${ }^{107}$

By making the legislature's current law the law of the private parties, the original balance of power is protected against inost legislative changes. Furthermore, a court at a later time is afforded unmistakable evidence of the original intention of the parties. If at the time Tu-Vu Drive-In Corporation was formed Mrs. Ashkins had persuaded her fellow investors to include a high-vote requirement (two-thirds) for amendment of the bylaws, sle would have gained protection from the insertion of transfer restrictions in the bylaws which would survive most statutory changes in the proportion of votes needed to amend the bylaws. ${ }^{108}$

107 Territorial choice of law clauses are often used even though they simply restate current territorial choice of law rules. The clauses remove some risks that the choice of law rules have been misinterpreted by the parties, and also protect against legislative or judicial changes in those rules.

Most territorial choice-of-law clauses simply say that the law of state $X$ shall govern some or all questions arising out of the contract. These clauses seem unsuitable as a model for an intertemporal choice-of-law clause. A draftsman might attempt to incorporate contemporaneous law into such provisions as voting majorities, class voting, cumulative voting or preemptive rights simply by a general choice-of-law clause which designates the general corporation law in effect at the time of incorporation as the law regulating these matters. But such a clause would not be the best solution to the problem of reliance on contemporaneous law. Among other deficiencies, including vagueness, such a clause might subject the parties to the risk of changing judicial and administrative interpretations of the incorporated statute (unless the clause ended with the words "as presently interpreted"), which in turn would raise difficult problems of research and proof.

108 Section 502 of the California Corporations Code, upon which the majority shareholder rehed to amend the bylaws, expressly permits article or bylaw adoption of a high-vote requirement for amendinent of the bylaws. Of course, this would not have protected Mrs. Ashkins against a new law outlawing high-vote requirements in existing as well as future corporations. 
III

NON-JUDICIAL CHOICE OF INTERTEMPORAL CORPORATE LAW

$T u$-Vu illustrates the extent to which intertemporal choices of corporation law have been relegated to the unlimited self-goverming machinery of the corporation itself. ${ }^{109}$ Reserved power clauses erased constitutional limits on the choice-of-law process and gave the legislature almost unlimited power to change corporation law. Modern corporation codes and doctrines have transferred much of this legislative power to the majority shareholders. Consequently, this area of the law lends itself to an examination of the capacities of different kinds of lawmakers for making intertemporal choices of law.

\section{A. Intertemporal Choice of Corporate Law by Shareholder Action (Example: Stock Transfer Restrictions)}

Stock transfer restrictions, such as those imposed by the majority in $T u-V u$, often are contained in both separate shareholder contracts and the articles or bylaws. Apart from doubt that such a restriction on transfer would be proper and enforceable if contained in articles or bylaws (without statutory authorization), ${ }^{110}$ a draftsmen is likely to place an agreement to give a first refusal offer in a contract executed by the parties. ${ }^{111}$ If the restriction is viewed as a contract, it caunot be imposed on a nonconsenting sliareholder. Each shareholder would then be free to agree or not to agree to restrict his shares; and an article or bylaw

${ }^{109}$ Tu-Vu Drive-In Corp. v. Ashkins, 61 Cal. 2d 283, 391 P.2d 828, 38 Cal. Rptr. 348 (1964).

110 In many states, statutes now provide that transfer restrictions are proper for articles or bylaws. See, e.g., Omo Rev. Code ANN. $\S \S 1701.04(B), 1701.11(B)(8)$ (1964); cf. Car. CoRp. Code $\S 305$; Dex. Code ANN. tit. 8, $\$ 102(\mathrm{~b})(1)$ (1964); N.Y. Bus. Corf. LAW $\S 402$ (b). And see N.Y. Bus. CoRp. LAw $\S 620(\mathrm{~b})$, requiring as a condition of validity that voting agreements in close corporations be contained in the articles.

These statutes probably were enacted to remove any doubt that transfer restrictions contained in a separate unanimous shareholder agreement could be restated in articles or bylaws, or that an agreement to restrict transfer could be placed in those documents rather than in a separate contract. In $T u$-Vu, bowever, the majority shareholder used the institutional machinery of bylaw amendment alone to impose on a nonconsenting minority holder a restriction usually considered to be a subject of voluntary contractual obligation.

Some cases have held that an article or bylaw which was invalid could nevertheless be enforced as a contract among consenting sharcholders. E.g., Mancini v. Setaro, 69 Cal. App. 748, 232 Pac. 495 (1924). One case held, however, that a clause (there it was a voting clause) which would have been valid in a separate contract was invalid as a bylaw and would not be enforced as a contract. See Sensabaugh v. Polson Plywood Co., 135 Mont. 562, 342 P.2d 1064 (1959).

111 O'Neal, Restrictions on Transfer of Stock in Closely Held Corporations: Planning and Drafting, 68 HARv. L. REv. 773, 785-88 (1952), recommends that restrictions be incorporated in a sliareliolder's agreement (as the basic locus) and in articles and bylaws as well to ensure an effective restraint. See generally Cataldo, Stock Transfer Restrictions and the Closed Corporation, 37 VA. L. REv. 229 (1951). 
restriction would be used only if all shareholders agreed, or would apply only to consenting shareholders. ${ }^{112}$

The Pennsylvania Supreme Court in Bechtold v. Coleman Realty Co., ${ }^{113}$ distinguished between bylaws primarily contractual and those primarily regulatory in nature, the former requiring unanimous consent for change but not the latter. Stock transfer restrictions were found to fall mainly in the contractual category. Therefore unaninous consent was required for amendment despite a statutory provision permitting amendment of bylaws by a majority of shareholders.

In contrast to $T u-V u$, Bechtold involved an attempt by the majority shareholder to remove, rather than to install, a stock transfer restriction in the bylaws. ${ }^{114}$ The origuial restriction had been adopted by unanimous shareholder vote at the organizational meeting. The court held that bylaw provisions which "are evidently designed to vest property rights inter se anıng all stockholders ... cannot be repealed or changed without the consent of the other parties whose rights are affected."115 Thus a vested (contract) rights doctrime was used to limit the permissible reach of the reserved power clause and statutory amendment provisions, a result dianietrically opposed to that in $T u-V u_{0}{ }^{116}$

112 The transfer restrictions could, however, be made to "run with the shares" so long as notice was given to each successive holder by some ineans, such as imprinting the restriction or a reference to it on the share certificates. See CaL. CoRp. COdE § 2404; CaI. CoMm. Code $\S 8204$.

$113367 \mathrm{~Pa} .208,79$ A.2d 661 (1951).

114 The supreme court's decision in $T u-V u$ does not represent a uniform judicial reaction to amendments inserting or removing transfer restrictions. In addition to the court in Bechtold and the lower courts in $T u-V u$ itself, other courts have taken different approaches, or, using the same approach, have reached a different conclusion. See, e.g., Casady v. Modern Metal Spinning \& Mfg. Co., 188 Cal. App. 2d 728, 10 Cal. Rptr. 790 (1961); Cowles v. Cowles Realty Co., 201 App. Div. 460, 194 N.Y. Supp. 546 (1922) ; Sandor Petroleun Corp. v. Williams, 321 S.W.2d 614 (Tex. Civ. App. 1959), noted 14 Sw. L.J. 106 (1960). But see Silva v. Coastal Plywood \& Timber Co., 124 Cal. App. 2d 276, 268 P.2d 510 (1954). See also the banking corporation cases cited in $T u$-Vu and discussed in Note, 53 CaIrF. L. REv. 692, $695 \mathrm{n} .22$ (1965). See generally Comment, 17 HASTINGS L.J. 583 (1966).

$115367 \mathrm{~Pa}$. at $213,79 \mathrm{~A} .2 \mathrm{~d}$ at 663 . It has been suggested that the vested rights doctrine has a place in limiting the exercise of reserved powers to affect rights which exist outside the charter. See Lynch, The Majority's Power to Effect Fundamental Changes in Shareholder Rights, 2 Corp. Prac. Comm., No. 4, pp. 1, 9 (1961). Since free transferability of personal property in general does not spring from the charter, the $T u$-Vu case would appear to be a prime context for application of that vested rights doctrine. But, in a jurisdiction that permits restrictions on transfer to be placed in the charter, free transferability does depend on the absence of a charter restriction. This demonstrates that, in general, the utility of categorizing rights existing inside and outside the charter is questionable, cf. Metzger v. George Washington Memorial Park, Inc., 380 Pa. 350, 110 A.2d 425 (1965) (extension of voting rights to preferred stock regarded as regulation of internal corporate affairs), although the concept does address itself to part of the problem of limits on the scope of the reserved power. See Note, 77 U. PA. L. REv. 256 (1928).

116 In Bechtold as in $T u-V u$ the general purpose of the stock transfer restrictions was to remedy the problem of competitors buying in and using their stock interests to the disad- 
Bechtold's emphasis on the contractual, as distinguished from the regulatory, nature of some articles or bylaws requires application of the law in effect at the time of incorporation or investment, and thereby prevents intertemporal choice of law by the majority shareholders. Presumably other bylaws having principally a contractual character hike stock transfer restrictions would be treated as are ordinary private contracts. The agreement may not be amended by one party to the contract without consent of all other parties. ${ }^{117}$ Some courts will not let the accident (or choice) of draftsmanship which incorporated the essentially contractual provisions into bylaws or articles rather than a separate contract produce a drastically different result in the balance of power.

The Bechtold approach presents at least two difficulties. First, the "regulatory" and "contractual" categories of bylaws are not self-evident. Many close-corporation bylaws other than stock transfer restrictions ${ }^{118}$ are arguably contractual in nature even though they have been included in the bylaws or the articles rather than separate shareholder agreements. Predicting whether unaminous consent or only a statutory majority will be necessary for amendment is not easy absent a very detailed statute. The Bechtold doctrine, therefore, presents difficult planning problems for the investor and his attorney.

Secondly, the Bechtold approach of protecting a minority by attempt-

vantage of the corporation. The fact that $T u-V u$ allowed insertion of the restrictions and Bechtold prevented removal invites a quick-but tentative-reconciliation of the cases on the ground that transfer restrictions are favored in a close corporation situation at least if solne showing of an impending threat of injury by coinpetitors is shown. They may be installed, but not removed, without unanimous consent.

As the text accompanying notes 155-56 infra suggests, the difference between installing and removing share transfer restrictions may be relevant to the limits on the lawnaking power of inajority shareholders in a closely held corporation. When a majority seeks to remove restrictions, one suspects the inotive stems from a desire on their part to sell their shares. And a selling majority cannot reliably be expected to concern itself with harm to the corporation, meaning the remaining sharelolders, that might ensue upon removal of the restrictions. If a majority seeks to impose transfer restrictions, the reason may be, as in $T u-V u$, that the minority has shown signs of wanting to sell out to an uncongenial buyer and the majority is seeking to protect itself and the corporation. To be sure, the majority may seek merely to place pressure upon the minority shareholders to force them to sell out to the inajority. But absent a showing of improper motives, an independent tribunal may tend to presume that corporate benefit inheres in mstalling transfer restrictions and individual benefit inheres in removing them.

117 Under this view, if a majority shareholder is subject to stock transfer restrictions like those in a separate shareholder contract whose violation could be restrained or remedied, he inay not violate them by the indirection of using his voting power in the corporate structure to delete the restrictions.

118 Examples of such bylaw provisions are voting limitations or agreements, pre-cmptive rights, special arrangements for dividends, and other control or financial devices that shape the closely held corporation much as a partnership agrecunent shapes a small enterprise in unincorporated form. 
ing to project the original understanding of the investors may impair the rights of the majority. Inclusion of stock transfer restrictions in the articles or bylaws which can be amended by a majority vote may have been a deliberate decision. If so, the investors who bought shares after the articles or bylaws contained a transfer restriction did so with the understanding that the restrictions might be amended or deleted at any time. Although the majority may not have wanted to delete the restriction at that time, the risk of change in the desires or composition of the majority was known or could have been ascertained by any investor when he bouglit his shares. He could have avoided the consequences of amendment or deletion by refusing to invest until a voting requirement sufficiently higli to give him a veto, or at least some increased protection, had been enacted. To protect him as the court did in Bechtold may be appropriate if it can be proved that no one intended the restriction to be controlled by fewer than all the shareholders; but no such proof is indicated in Bechtold. Thus the decision may have failed to give effect to the tacit understanding of the parties. ${ }^{119}$

Even if Bechtold's result is questionable, ${ }^{120} T u$-Vu is not therefore beyond question. Tu-Vu's refusal to accept Bechtold's distinction between regulatory and contractual bylaws, or between those dealing with the internal affairs and other matters, emphasizes the principles of majority rule. Lacking any express qualification, the supreme court's opinion in $T u-V u$ seems to say that a minority is virtually unprotected against a change in corporate law in the absence of agreement to give that minority a veto. ${ }^{121}$

119 This problem is somewhat like that raised by an indenture or preferred stock contract which contains no antidilution clause when dilution of a shareholder's investment will follow from literal interpretation of the contract. For example, a stock dividend on shares into whieh another security is convertible, or sale of conversion shares below the conversion price, will raise this problem. Courts have been reluctant to read in antidilution provisions. See, e.g., Sutliffe v. Cleveland \& Mahoning R.R., 24 Ohio St. 147 (1873). See generally Buxbaum, Preferred Stock-Law and Draftsmanship, 42 CAIm. L. Rev. 243, 279, 282 (1954). Yet the decision in Bechtold ainounts to reading a unanimous-vote requirement into the bylaws. It, therefore, either overrides the statutory voting provisions or ignores the usual doctrine that contemporaneous corporation law and the reserved power clause are a part of the articles and bylaws of a corporation.

120 The case has been criticized. See Note, 100 U. PA. L. REv. 133 (1951).

121 Perhaps $T u-V u$ need be taken to mean this. In fact, the decision by the supreme court in $T u-V u$ may rest on the peculiar facts of that case and the imferences the court may have drawn from those facts. Discussions with counsel for the corporation revealed that $\mathrm{Tu}-\mathrm{Vu}$ Drive-In Corporation had been formed somewhat hurriedly to enable Mr. Russo and Mr. Ashkins to acquire the assets of a drive-in moving picture business. Mr. Russo was the owner of several drive-ins and Mr. Ashkins became manager of $\mathrm{Tu}$-Vu and a director; "his" stock was held in his wife's name. Russo was president of the corporation, however, and eventually discharged Mr. Ashkins, who then planned to withdraw from Tu-Vu altogether. Ashkins then discussed with Sero Amusement Coinpany-an operator of many drive-ins and 
The Bechtold analysis in terms of contractual and regulatory bylaws would not, however, automatically solve the $T u$-Vu problem. In Bechtold, unamimous shareholder agreement had imposed contractual obligations on the shareholders. In $T u$-Vu there was no express agreement to maintain free transferability of shares. Nonetheless, $T u-V u$ can be seen as presenting elements of contract not much different from those in Bechtold. A contract shapes legal relationships by spelhing out the terms of those relations to the extent they will not otherwise exist under contemporaneous law. By omitting clauses that would change the effect of existing law, contracting parties tacitly agree to accept that effect. In this sense, contemporaneous law, at least to the extent it is perceived as pertinent, is adopted and relied upon by the parties and leads to expectations as much as any express provision of their contract.

In $T u-V u$, as in Bechtold, the law was changed before all the relevant events had occurred. The cliange did not alter the effect of a transaction already consummated as it would if a transfer completed before the change in law had been rendered ineffective by the bylaw amendment. The changes of law in $T u-V u$ and Bechtold appear to affect only the future sales of shares. ${ }^{122}$ However, the changes were retroactive in the sense that they applied to shares purchased before the bylaw amendment.

Tu-Vu's main competitor-the sale of his shares to Sero at a profit. In anticipation of the problems that would be presented by a competitor owning thirty-nine per cent of Tu-Vu's shares (a proportion that would, with cumulative voting - which is mandatory in California - enable the competitor to gain a place on Tu-Vu's board which, under Cahiformia law, would have to consist of at least three directors), Mr. Russo obtained, then allowed to lapse, an option to purchase Mrs. Ashkins' shares before she gave an option to Sero. After the decision in $T u-V u, M r$. Russo did purchase Mrs. Asbkins' shares at approximately the same price at which she had agreed to sell them in her first option to Mr. Russo and two later options to Sero, a price in excess of the cost of the shares in 1958, approximately six years earlier. There is no rehiable indication of the price Mrs. Ashkins might have been able to obtain from Sero or an imdependent purchaser in 1964 if there bad been no first refusal restriction applicable to the shares.

In other words, if facts such as these could bave been employed by the court in a somewhat different opmion to support the same holding, the case could be taken to indicate that California courts will scrutinize majority amendments and weigh the legitimate corporate benefits against legitinuate minority arguments of disadvantage in reaching a judgment on whether new bylaws will bind outstanding shares. This meaning is not given to the case by the opinion, however; and, even if read into the case, it does not explain the Commissioner's failure even to hold a hearing on the amendments (applicable to shares of which the Coinmissioner was the escrow holder) or give notice to Mrs. Ashkins so that she could have objected before the Commissioner, whose issuance of a permit must have had some persuasive effect on the court.

122 In this respect, $T u-V u$ and Bechtold are different froin the accumulated-dividend cases where dividends accrued before the amendment were destroyed. This extra element of retroactivity may account for the reluctance of some courts to permit eradication of accrued dividends by simple charter amendment, see Keller v. Wilson \& Co., 21 Del. Ch. 391, 190 Atl. 115 (Sup. Ct. 1936), and Consolidated Film Indus. v. Johnson, 22 Del. Ch. 407, 197 Atl. 489 (Sup. Ct. 1937), while tolerating changes in the future dividend rights or rates of 
The change of law in $T u-V u$, unlike that in Bechtold, represented a change from the residual law of free transferability to a private, individual law resting on agreement. Although in general our legal system precludes one person from subjecting another to private, contractual law without his consent, $T u$-Vu allowed the majority shareholder to do just that to the nonconsenting minority. $T u-V u$ therefore raises the question of the extent to which the majority may use its power over the corporate structure to impose new rules or obligations upon the minority when the minority claims that such power was not conferred on the majority at an earlier time. ${ }^{123}$

Some courts have found limits on majority power by concluding on a case-by-case basis that the majority exceeded its statutory power. The purposes for which articles may be amended and the kinds of new provisions they may contain are customarily set forth in a statute. ${ }^{124}$ Broad as some of those provisions are, they generally confine the permissible area of amendments to matters directly relatimg to the corporation. Their looser terms, such as "to classify and reclassify" shares, have been construed as words of art and limited to amendments of a conventional, internal corporate nature. ${ }^{125}$

In addition to terms referring to generic corporate changes other more elastic statutory clauses authorize such amendments as "any other change or alteration in [the] certificate of incorporation that may be desired."126 If the amending power is qualified by language limiting amendments to "only such provisions as might be lawfully contamed in an original certificate of incorporation filed at the time of making sucl amendment,"127 and if the provisions which might be contained in an original certificate are

previously issued and outstanding shares, as in Harbine v. Dayton Malleable Iron Co., 61 Ohio App. 1, 22 N.E.2d 281 (1939).

123 Could the majority, for example, amend the articles to compel minority shareholders to convey their shares to the corporation without compensation, or in return for nominal consideration, or even for fair value? One's instinct is to say no, and some cases intimate as much when they refuse to countenance changing nonredeemable shares into redeemable shares without the consent of the sharcholder. See, e.g., Outwater v. Public Serv. Corp., 103 N.J. Eq. 461, 143 Atl. 729 (Ch. 1928) aff'd, 104 N.J. Eq. 490, 146 Atl. 916 (Ct. Err. \& App. 1929); Breslav v. New York \& Queens Elec. Light \& Power Co., 249 App. Div. 181, 291 N.Y. Supp. 932 (1936), af'd, 273 N.Y. 593, 7 N.E.2d 708 (1937); Yukon Mill \& Grain Co. v. Vose, 201 Okla. 376, 206 P.2d 206 (1949). Contra, Donohue v. Heuser, 329 S.W.2d 238 (Ky. 1951); Cowan v. Salt Lake Hardware Co., 118 Utah 300, 221 P.2d 625 (1950); cf. Clarke v. Gold Dust Corp., 105 F.2d 598 (3d Cir. 1939).

124 See, e.g., Cal. Corp. Code $\S \S 3600-04$; Del. Code ANN. tit. $8, \S 242$ (1953); N.Y. BUS. CORP. LAW § 801; Omo REv. CODE ANN. § 1701.69 (1964).

125 See, e.g., Breslav v. New York \& Queens Elec. Light \& Power Co., 249 App. Div. 181, 291 N.Y. Supp. 932 (1936), aff'd, 273 N.Y. 593, 7 N.E. 708 (1937).

126 See, e.g., Dex. CODE ANn. tit. 8, \$ 242 (a) (5) (1953).

127 See, e.g., N.Y. Bus. Corp. LAW $\$ 801$ (a). See also Onno Rev. Code ANn. § 1701.69(A) (1964). 
carefully specified, ${ }^{128}$ this interlock provides protection against some misuses of the amending mechanism. Often, however, the limitation afforded by the statute on original articles is vague at best. The scope of original articles may be very broad. ${ }^{129}$ Many clauses, such as share transfer restrictions, which seem unobjectionable in original articles take on a different flavor when imposed on outstanding shares. Consequently, in interpreting statutory power to amend articles or bylaws, the issue can be framed in terms of whether the legislature intended to authorize such articles as amendments with respect to outstanding shares or only for shares to be issued in the future. From the legislature's point of view, two kinds of questions are presented: the appropriate temporal scope of statutory amendment powers, and the desirability of according identical amendment powers to shareholders of all-publicly held and closecorporations.

\section{B. Intertemporal Choice of Corporate Law by Legislative Action (Example: Cumulative Voting)}

Discussion of the $T u-V u$ case has focused on the power of majority shareholders to apply new rules, cast in the form of bylaw or article amendments, to non-consenting holders of outstanding shares. Statutory change in the majority's amending power after the minority's shares were issued has not been part of the analysis. ${ }^{130}$ The presence of legislative change in addition to or underlying shareholder change adds a dimension of coinplexity to the problem that has been too often overlooked.

If shareholder amendments are possible only because of legislative changes that followed issuance of the dissenting minority's shares, two intertemporal conflicts of law are presented. ${ }^{131}$ To illustrate, assume that

128 See, e.g., N.Y. Bus. CoRP. LAW $\S 402$ (a); OHIo Rev. Code ANN. § 1701.04(A) (1964).

120 See, e.g., N.Y. Bus. CoRp. LAW § 402(b), OHIo REv. CODE ANN. § 1701.04(B) (1964).

130 Nevertheless, since the majority's power in $T u$-Vu stemmed entirely from the statutory authority delegated by the legislature in the exercise of its reserved (or imherent) power, some of the problems raised by $T u-V u$ are ultimately ones of legislative drafting and himits on legislative power.

131 Voting rights can be modified in a multitude of ways, though the following text deals mainly with cumulative and straight voting laws. Cases involving amendinents in voting characteristics are collected at LATrin \& Jennangs, Cases on Corporatrons 1323-24 (3d ed. 1959); Note, 15 S.C.L. REv. 506, 535-37 (1963). An important and illustrative interteinporal voting case is Faunce v. Boost Co., 157 N.J. Super. 534, 83 A.2d 649 (1951) (analyzed, somewhat in temporal terms, in Note, 37 ConNerc L.Q. 768 (1952)); compare Milwaukee Sanitarium v. Lynch, 238 Wis. 628, 300 N.W. 760 (1941).

Some cases have held that new voting statutes are not applicable to pre-existing corporations, for a variety of reasons. See, e.g., Smith v. Atchison, T. \& S.F.R.R., 64 Fed. 272 (C.C. Kan. 1894); Orme v. Salt River Valley Water Users Ass'n, 25 Ariz. 324, 217 Pac. 935 (1923); State ex rel. Haeussler v. Greer, 78 Mo. 188 (1883); Hays v. Cominonwealth, 82 Pa. (1 Norris) 518 (1876); State ex rel. Starkey v. Alaska Airlines, Inc., 68 Wash. 2d 297, 413 
at time one ( $T 1$ ), when a corporation was formed and shares were issued, cumulative voting in the election of directors was mandatory under the state corporation statute. ${ }^{132}$ Assume also that the statute (1) authorized articles of incorporation to include, in addition to specified clauses, any other provision "not in conflict with law;"133 and (2) permitted a corporation's articles to be amended to make "any other change or alteration in its certificate of incorporation that may be desired," provision of the articles or add any provision that may properly be included therein,"135 or to contain "such provisions as inight be lawfully contained in an original certificate of incorporation filed at the time of making such amendment."136 Then assume that at time two (T2) the state legislature amended the corporation law to permit a corporation to elect straight voting by a charter or bylaw provision. ${ }^{137}$

The main purpose of this law enacted at $T 2$ would be to permit corporations thereafter formed in the state to govern themselves by straight

P.2d 352 (1966); State ex rel. Swanson v. Perham, 30 Wash. 2d 368, 191 P.2d 689 (1948). Pre-existing corporations may, however, be brought within the new voting law if they expressly submit to it, accept benefits of the legislation or take action under subsequent legislation, the acceptance of whose benefits is conditioned on acceptance of the cumulative voting provision. See, e.g., cases collected in Annot., 43 A.L.R.2d 1322 (1954). Subsequent voting statutes have been applied to pre-existing corporations formed under statutes reserving the right to amend the charter or bylaws. See, e.g., Annot., supra, and cases collected therem; Maddock v. Vorclone Corp., 17 Del. Ch. 39, 147 Atl. 255 (Ch. 1929) (charter amendment); Quilliain v. Hebbronville Util., Inc., 241 S.W.2d 225 (Tex. Civ. App. 1951) (bylaw amendment).

132 California has such a statute. CaL. CORP. CODE $\$ 2235$. See also CaL. CORP. Code $\$ 810$ providing for cumulative voting on removal of a director. A similar statute, but one which specifies sharcholder demand as a precondition, is Oml REv. CODE ANN. \$ 1701.55 (1964). Under sucl statutes, no origimal articles could be filed if they provided for straight voting (or such provision would be ineffective), and no amendment could lawfully impose straight voting.

133 See, e.g., Cat. Corp. Code $\S 305$ (c). Morris v. American Pub. Util. Co., 14 Del. Ch. 136, 122 Atl. 696 (Ch. 1923), held that such a statute did not authorize cancellation of accrued cumulative dividends by charter amendment.

134 Cf. Dex. Code ANN. tit. § 242(2) (5) (1953). In Patterson v. Durlaam Hosiery Mills, 214 N.C. 806,200 S.E. 906 (1939), the court held that a statute generally authorizing ainendinents to reclassify shares would not operate "retrospectively" to cancel accrued cumulative dividends. The problem of accrued dividends adds another dimension to the retroactivity problems of cumulative voting, pre-emptive rights, and share transfer restrictions. Destruction of accrued dividends involves retroactivity in the primary sense (see text accompanying notes 144-46 infra) in that it attempts to alter the effect of prior events not just from the date of the new action but as of the date of the prior events.

135 Cf. OHIO Rev. CODE ANN. \& 1701.69(11) (1964).

136 Cf. N.Y. BUS. CORP. LAW $\$ 801$ (a).

137 The hypothetical case described in the text parallels the facts of State $e x$ rel. Starkey v. Alaska Airlines, Inc., 68 Wash. 2d 297, 413 P.2d 352 (1966). In that case, however, no reserved power clause had been in effect in the jurisdiction of incorporation, whose law applied under usual interterritorial conflict of laws principles. Consequently, the court lield, minority shareholders had a right to cumulative voting that the legislature could not change because of the rule in the Dartmouth College case. 
voting. However, because the section of the corporation code which permitted amendments to the articles was geared to the section prescribing the content of original articles, the effect of prospectively eliminating the cumulative voting requirement (as to corporations thereafter formed) will also be to eliminate it retroactively (as to pre-existing corporations and outstanding shares). After the legislative amendment, a pre-existing corporation apparently may change its voting procedures from cumulative to straight voting by article amendment adopted by a statutory majority of the shareholders. ${ }^{138}$

A legislative change from mandatory cumulative voting to permissive straight voting will have different intertemporal implications from legislative repeal of the cumulative voting requirement, or legislative change from mandatory cumulative voting to permissive cumulative voting (if cumulative voting is expressly elected), or legislative adoption of mandatory straight voting. If the new statute decrees that directors are to be elected by cumulative voting unless an article or bylaw otherwise provides, pre-existing corporations will be governed by cumulative voting unless and until holders of outstanding shares amend the articles to adopt a straight voting clause. Future corporations similarly will be compelled to cumulate votes unless in original or amended articles they provide otherwise. But if the legislature, instead of permitting charter provisions to waive or elect cumulative voting, adopts mandatory straight voting rules, all corporations-pre-existing as well as later-formed-will not be able to choose any other system. ${ }^{139}$ Elections conducted before the change in statutory law would, however, presumably still be valid even though

138 This result may be entirely consistent with legislative purpose. Having decided to permit some (future) domestic corporations to operate without cumulative voting, the legislature might well have intended that its new policy apply to all domestic corporations. However, it is quite possible that the impact of the statutory change in policy on pre-existing corporations and outstanding shares was not deliberately intended or even considered by the legislature.

It is also highly probable that the different impact such a legislative change would have on shareholders in close corporations as opposed to those in large publicly held corporations was neither recognized nor considered by the legislature. The importance of the voting characteristics of shares to a given shareholder increases with the closeness of the corporation's holdings and the proportion beld by that sharcholder. A change from cumulative to straight voting can dramatically shift the allocation of power and control from one shareholder faction to another in a closely held corporation. Therefore, voting characteristics of shares often are central to investment decisions in closely held corporations.

139 If state law is amended to make straight voting mandatory, the minority shareholder loses important protections, unless he can successfully raise constitutional or vested rights objections, which is unlikely. Furthermore, there is nothing he could have done earlier to protect himself by blocking the change in law. If, on the other hand, the legislative change had been from mandatory cumulative voting to permissive straight voting, his situation would then depend on whether voting is cumulative unless otherwise specified in the articles, or straight unless otherwise so specified. 
conducted by cumulative voting. The basic intertemporal choice-of-law rule would then be that the law in effect at the date of an election governs the validity of that election, although that law may be changed between elections. The date of fonnation of a corporation or the date its shares were issued will then be completely irrelevant; whereas in the event a mandatory cumulative voting rule were changed to permissive straight voting, it would have had a presumptive or initial impact until and unless article or bylaw amendments were adopted to change the rules. ${ }^{140}$

When legislative changes, such as one from mandatory cumulative to mandatory straight voting, are sanctioned by the courts, the decisions in effect hold that a corporation formed at $T 1$ does not have throughout the duration of its existence an indefeasible right to application of the law on director elections in effect at $T 1{ }^{141}$ Yet, in another way, a fixed intertemporal result is adopted if the director elections conducted between $T 1$ and $T 2$ are thereafter lield valid because they complied with the law in effect at the time of the election. The corporation is thus held entitled to have the law temporally accompanying an election applied to that election. Such a decision permits retroactivity only insofar as a law enacted or adopted after the election applies to pre-existing corporations. ${ }^{142}$ The

140 To protect against legislative amendment of the mandatory cumulative voting statute to permit straight voting when the articles or bylaws waive cumulative voting, a minority shareholder should-before investing-attempt to obtain, if not already provided by statute, the additional safeguard of a high-vote requirement for amendment of articles and bylaws. Then, if the statute is amended to permit waiver of cumulative voting, the minority can prevent the majority from inserting the waiver.

But a high-vote requirement will not protect the mimority if the statute is changed from one making cumulative voting mandatory to one prescribing straight voting unless cumulative voting is required by the articles or bylaws. In this event, the majority does not need to amend the articles or bylaws to take advantage of straight voting and the minority's veto is useless. However, protection for the minority against this kind of legislative change would be afforded if the cumulative voting provision of the former law on which the minority holder relied were restated in the articles and combined with a high-vote requirement for amending the articles. Then any atteinpt by the majority to change the system of voting would be subject to the minority holders' veto.

This technique of restating contemporaneous law parallels the boiler plate choice-of-law clauses often imcluded in corporate acquisition agreements and other contracts. Rather than generally specifying the applicable law in terms of time ("the law in effect at this time, as presently interpreted"), restatement of current law adopts the statute as part of the parties' own agreeinent.

For a discussion of autonomy in the choice of territorial law by contractual stipulation (professio juris), see EHRENzWEIG, Conflict of LAws 455-58, 467-70 (1962). Restatement of contemporaneous law is also somewhat analogous to prorogation clauses whereby contracting parties seek to oust some courts of jurisdiction and to ensure that adjudication or arbitration will take place in named tribunals. On prorogation, see id. at 147-59.

141 For related problems in connection with changes in state law apphicable to election of public officials, see, e.g., Romiti v. Kerner, 256 F. Supp. 35 (N.D. Tll. 1966).

142 This result is analogous to the usual choice of territorial law decision which apphes the law of the state of incorporation (the local law, territorially) to test the validity of a 
law is thus allowed to change from time to time by legislative, shareholder or even director action and to have some bearing on prior events, but not to change the legal consequences of those events as of the time they occurred. ${ }^{143}$ This interaction between legislative changes in the corpora-

corporate election. Such was, in practical effect, the decision in Maddock v. Vorclone Corp., 17 Del. Ch. 39, 141 Atl. 255 (Ch. 1929) ; Metzger v. George Washington Meinorial Park, Inc., $380 \mathrm{~Pa} .350,110 \mathrm{~A} .2 \mathrm{~d} 425$ (1955). When those cases upheld a change in the law from straight to cumulative voting ( $M a d d o c k$ ) or froun nonvoting to voting preferred stock (Metzger), they implicitly premised their decisions on an intertemporal choice of the law contemporaneous with the election.

Cases, such as Berger v. Amana Soc'y, 250 Iowa 1060, 95 N.W.2d 909 (1959); Sensabaugh v. Polson Plywood Co., 135 Mont. 562, 342 P.2d 1064 (1959); and Faunce v. Boost Co., 15 N.J. Super. 534, 83 A.2d 649 (1951), by refusing to uphold an attempt by majority sbareholders to cbange the voting characteristics of shares by article amendment, constitute a choice of the law in effect at some other time for application to the validity of director election or other vote. The law in effect at the time of incorporation or issue of a dissenter's shares is held to govern the validity of later votes when an attempt to change the law before a later vote is lield impermissible. If the decision rests on grounds of statutory interpretation, it amounts to discerning the law of which time the legislature uneant to be applicable. If it rests on fairness, it is an exercise of judicial power to choose law inter-temporally beeause of the unfairness of applying later law to earlier transactions. On the other band, if the unfairness results from other factors, such as an attempt by a majority to freeze out a minority with no independent corporate purpose, the decision is not rcally an intertemporal choice of law; it is simply a decision by a court of equity to apply one legal rule rather than another largely for nonteinporal reasons.

143 Legislative changes in pre-emptive rights involve problems of investor reliance and approaches to construction of subsequent legislation similar to those resulting froun changes in the law of cumulative voting. Many shareholders in closely beld corporations rely on a right to maintain their proportion of the earnings and control of the corporation by a first refusal option on any new issue of shares. In many states common law pre-emptive rights have been destroyed by statute and a shareholder will be entitled to a pre-emptive right only if the articles, or perhaps the bylaws, of the corporation grant that right. (See, e.g., Car. CORP. CODE $\S \S 305,1106,1108$.) In such jurisdictions most lawyers advising a potential sbareholder in a close corporation are sensitive to the need for an express grant of pre-emptive rights in the articles and, because the articles can be amended by a vote of fewer than all the shareholders, the desirability of including a high-vote requirement to protect against deletion of a pre-emptive rights clause. Absence of a pre-emptive rights clause or a high-vote provision in the articles, if none is provided by law, suggests that the original investors agreed to forego those protections or, at least, that those who wanted the protections were unable to obtain them. In such event, an amendinent of the articles or change in state law that denies pre-eunptive rights probably does little violence to the original understanding. Assume, however, that at the time of incorporation, pre-emptive rights were accorded by statutory or common law unless waived by the articles. (Many state statutes grant pre-emptive rights as at common law or as specified by statute unless the articles otherwise provide. See, e.g., Des. Code Ann. tit. 8, § 102(b) (3) (1953); N.X. Bus. Corp. Law § 622; Omo Rev. Code ANN. \$\$ 1701.06, 1701.15 (1964).) In such a case, failure to imsert a pre-emptive right article buttressed by a high-vote requirement does not suggest agreeinent to forego that protection. It suggests, if anything, rchance on existing law to afford protection against dilution of a shareholder's position by new issuance of shares. A later attempt to abolish pre-emptive rights would thus constitute an important departure from the original understanding of the investors. It is submitted that aubiguous statutes should be construed as operating prospectively only, and a permit system should be administered to respond to these differences in case histories.

Cases involving amendments of articles or bylaws to insert or remove pre-emptive rights 
tion law and shareholder changes which depend upon legislative changes should be examined in light of policy factors peculiar to that interaction. Such factors stem from differences between legislatures and shareliolders as lawmaking bodies, differences between closely held and public corporations as subjects of changes in the law, and differences between the kinds of changes in the law and the kinds of rights affected by those changes. These differences and their policy implications are explored in the final part of this article.

\section{IV}

\section{GUIDELINES FOR INTERTEMPORAI CHOICE OF CORPORATE LAW}

The almost unrestricted freedom of state legislatures to apply law in any direction or extent over time has led to especially serious problems when the legislature's power to make changes is delegated to private lawmaking groups, such as shareholders and directors. Those problems are

have gone both ways. See, e.g., Gottlieb v. Heyden Chem. Corp., 33 Del. Ch. 82 , 90 A.2d 660 (Sup. Ct. 1952) (amendment to remove pre-emptive rights permitted). The court in Gottlieb did not indicate whether the corporation had been formed before enactment of the statute which permitted waiver of common law pre-emptive rights (DEL. CODE ANN. tit. 8, $\S 102(\mathrm{~b})(3)(1953)$ ) or what the significance of that might have been. In Yoakain v. Providence Biltmore Hotel Co., 34 F.2d 533 (D.R.I. 1929), the corporation involved had been formed before enactment of $\S 102(\mathrm{~b})(3)$. After enactment, the majority shareholders amended the charter to abolish pre-emptive rights and dissenters objected. The court failed to pass on the validity of the amendment, however, because an issuance of shares was not imminent. The court indicated that the amendment would be valid per se but that its role could give rise to equitable considerations of which a court might take cognizance when additional shares were to be issued.

In Milwaukee Samtarium v. Lynch, 238 Wis. 628, 300 N.W. 760 (1941), deletion of preemptive rights by amendment was permitted on the theory that an investor consents in advance to the unaking of such changes in articles as the statutes in effect at the time of his acquisition permit. Changes in the voting requirements for amendment of the articles also present problems similar to those arising when the law on cumulative voting is changed. Assume tliat at the time the original articles are filed state law requires a vote of more than a majority of the outstanding shares (and/or a class vote) to amend articles. (See, e.g., Car. CoRp. CoDE $\$ \S 3634$ (two-thirds vote by class for specified amendments) and 3635 (majority vote of all shares other than those benefited by certain amendinents); OHIO REV. CoDE ANN. $\S 1701.71$ (1964) (high-vote and class-vote requirements on specified amendments). Compare DEI. Code ANN. tit., 8, § 242 (1953) (majority only); N.Y. BUS. CORP. LAW § 804 (majority vote, by class, on specified amendments).) In such a jurisdiction, the original mvestors will probably rely on the high-vote or class-vote requirements of contemporaneous law and not repeat such requirements in the articles. A statutory amendment would upset the parties' understanding if it reduced the majority needed to a simple majority in tile absence of higher vote requirements in the articles. The majority could then override a minority which could have blocked the amendment under prior law. However, the minority could have protected itself against tlis change in the law, if it recognized the necessity, by restating in the original articles a high-vote or class-vote requirement.

Incorporation of existing law as a protection against legisiative amendments may thus be a desirable procedure as a drafting matter for the practicing lawyer. Simce it is not a commonly employed technique, however, failure to use it should not be construed as a deliberate agreement to risk any and all changes in the law. 
accentuated in closely held corporations. When monitoring the continuing tension between stability and change, legislatures, courts and administrators should adopt different guidelines for intertemporal choices of law for, on the one hand, shareholder action in closely held corporations and, on the other hand, shareholder action in publicly held corporations. Moreover, when faced with a conflict of corporate laws in time, all lawmakers must reconcile the competing interests of the state in facilitating corporate flexibility and protecting investor reliance. In achieving this reconciliation, the lawmaker should consider not only the type of corporation affected but also whether the change in law is produced by sliarelolder or legislative action.

Legislative enactments usually operate prospectively; that is, they govern legal consequences of events occurring after the date of enactment. Sometimes, however, statutes act retroactively in a primary sense: They reach "back to attach new legal riglits and duties to already coinpleted transactions." ${ }^{\text {"144 }}$ A statute retroactive in this primary sense alters

144 Hochman, The Supreme Court and the Constitutionality of Retroactive Legislation, 73 HARv. L. REv. 692 (1960). For example, if one who commits a homicide that was innocent or privileged when committed is later punished as a result of a subsequent law making the homicide a crime and removing the privilege, the law is retroactive in the primary sense and, in this country, unconstitutional under the ex post facto clause. A law making prior contracts, valid when signed, invalid for all purposes from the date of execution would similarly be called retroactive in the primary sense. See generally Greenblatt, Judicial Limitations on Retroactive Civil Legislation, 51 Nw. U. L. REv. 540 (1956); Slawson, Constitutional and Legislative Considerations in Retroactive Lawmaking, 48 CArrs. L. Rev. 216 (1960); Sinead, The Rule Against Retroactive Legislation: A Basic Principle of Jurisprudence, 20 MinN. L. Rev. 775 (1936); Smith, Retroactive Laws and Vested Rights, 5 Texas L. Rev. 231 (1927), 6 Texas L. Rev. 409 (1928). See also Scurlock, Retroactive Legistation AFFECTING INTERESTS IN LAND (1953).

A number of retroactivity problems crop up in federal tax law and administration. See generally Amberg, Retroactive Excise Taxation, 37 HARv. L. Rev. 691 (1924); Ballard, Retroactive Federal Taxation, 48 HARv. L. REv. 592 (1935); Neuhoff, Retrospective Tax Laws, 21 St. Louss L. Rev. 1 (1935); Stimson, Retroactive Application of Law-A Problem in Constitutional Law, 38 Micr. L. Rev. 30 (1939). And see HarT \& SACrs, The Leons, Process: Bastc Probiems in the Maring and Appitcation of Law, 644-46 (tent. ed. 1958); Novick \& Petersberger, Retroactivity in Federal Taxation, 37 TAXEs 407; 499 (1959); Williams, Retroactivity in the Federal Tax Field, 1960 So. CAurF. TAX INST. 79.

An illuminating discussion of retroactivity in tax cases may be found in the several opinions in James v. United States, 366 U.S. 213 (1961). For a leading case on collateral estoppel, res judicata and change of law in tax cases see Commissioner v. Sunnen, 333 U.S. 591 (1948), where the problems of equality are stressed. As to interest on amounts "underpaid" as retroactively determined in light of changed interpretations of the law, see Priess v. United States, 42 F. Supp. 89 (E.D. Wash. 1941), and sources cited in BITTKER, FEDERAL Income, Estate and GIts TaXation 945 (3d ed. 1964).

Dean Griswold las said, "No federal income tax has ever been held invalid on the ground that it was retroactive," although le cites one case, People exr rel. Beck v. Graves, 280 N.Y. 405, 21 N.E.2d 371 (1939), holding that retroactivity of sixteen years in a state tax was "too nuch." See Grisword, Federar Taxation Cases 130 n.3 (6th ed. 1966). 
the legal consequences of past events as of the time of those events. But statutes which purport to have only post-enactment effect may also be classified as retroactive insofar as they bear importantly on prior events by affecting their future legal consequences as of the time the new law is adopted. ${ }^{145}$ Such retroactivity is illustrated by a statute declaring pre-existing obligations unenforceable in the future. This is retroactivity in the secondary sense. ${ }^{146}$

145 A Canadian case, Emerson v. Skinner, 3 W.L.R. 558 (1906), illustrates this point. Prior to enactment of a statute prohibiting the export of timber from British Columbia, the defendant had cut some trees and apparently had contracted for an export sale. The court construed the statute as not applicable to the defendant by applying the common-place rule that legislation is presumed to operate prospectively only, in the absence of express or clearly implied legislative intent otherwise. See Kavanagh, Retrospective Operation of Law, in 4 Colizction des Travaux de ia Faculté de Droit de L'Untversité D'OtTaWa (Proceedings of the Third Int'l Symposium on Comparative Law) 28, 29 (1965).

The range of retroactivity in contract cases is large. The change in law may have a retroactive effect, in some sense, if it becomes effective after the contract is made but before breach, after breach but before the cause of action has accrued, or before further events going to the claim or defense have occurred, after the cause has accrued but before an action has been filed, after filing but before trial, during trial, after trial but before decision, before appeal, before final appeal, and so on. This range of instances corresponds to the range of the intertemporal choice of law open to a court faced with a change at any relevant stage of the case before it. Cf. HART \& SACRS, op. cit. supra note 144, at 646-49. A case in a very different substantive law area but involving similar problems of deceptive retroactivity is Pitts v. Perluss, 58 Cal. 2d 824, 377 P.2d 83, 27 Cal. Rptr. 19 (1962). There the Supreme Court of California mechanically allowed itself to be persuaded that application of new msurance regulations to prevent private insurance companies from substantially selecting risks for unemployment compensation insurance, and thus adversely affecting the state disability fund, was not retroactive legislation and therefore was not invalid. Since insurance companies had established plans previously in reliance on then current regulations, it does not fully meet the problem to say that imposing standards for future operation of insurance plans "does not impose new legal sanctions upon the past action of the insurance companies . ..."Id. at 836,377 P.2d at 90, 27 Cal. Rptr. at 26.

146 A distimction between kinds of retroactivity along much the same lines as the "primary" and "secondary" descriptions used here is offered in Slawson, supra note 144, at 220.

In corporation law, as in any substantive area, new rules sometimes have a retroactive impact in the primary sense, by altering the legal significance of past transactions not only from the date of the new rule but from the time those transactions took place. But more often they are retroactive in the secondary sense. Retroactivity in this secondary sense is the principal focus of this article. The doctrime that historically has been employed to block such interference with prior rights, obligations or privileges is not, strictly speaking, the rule against retroactive lawmaking, but the doctrime of vested rights. One striking example of secondarily retroactive legislation with respect to corporate problems is the amendinent in 1965 to $\S 2231$ of the California Corporation Code which inserted the itahicized words and omitted the bracketed words in the section as follows: "Any trust, heretofore or hereafter created, the sole or principal purpose of which is the voting or representing of shares, may be terminated at any time by the holders of a majority in interest of the beneficial interests therein [unless otherwise specified therein]. No such voting trust shall be made irrevocable for a period of nuore than 21 years." Before its amendment, $\$ 2231$ permitted a voting trust to "otherwise specify," to require a vote higher than a simple majority for termination. Such other specification, made when the former version of $\$ 2231$ expressly authorized it, apparently 
Whether a court decision enunciating a new rule of law or overruling precedent operates prospectively or retroactively or both, depends upon the temporal limits placed on the decision by the court, and whether the decision is viewed as precedent or as the law of the case. As the law of the case, a court decision is retroactive in the primary sense if it declares rights and liabilities of parties after the time the relevant events occurred as of the time of their occurrence. This is typically recognized as a retroactivity problem only if the court's decision involves more than the routine application of existing rules of law, or, in other words, the making of new law. If the law of the case operates from the date of decision only, as, for example, an mjunction does, and does not affect the legal consequences of prior events as of the time of their occurrence, it is retroactive only in the secondary sense.

A court decision as precedent usually has both the prospective effect of a statute, insofar as it changes the legal consequences of events postdating the decision, and a retroactive effect, insofar as it is applied to other parties and controversies that arise out of events antedating the decision. If a court decision changes the law that apparently was applicable to antecedent events when they occurred, as of the time they occurred, the decision as precedent is retroactive in the primary sense. Examples of this are afforded when the new decisional doctrine is applied to void a conveyance that was valid when made or to upset a criminal conviction. On occasion, courts limit the temporal scope of their decisions as precedent by the technique of "prospective overruling."147

is rendered ineffective from the date of the 1965 anendment. One case illustrating a judicial distinction between kinds of retroactivity is Ramey v. Michel, 6 Cal. 2d 259, 57 P.2d 932 (1936). The California Supreme Court there held that legislation could constitutionally impose personal liability on a shareholder with respect to shares lie liad purchased prior to passage of the legislation but not with respect to debts incurred before its passage. To allow the latter, the court said, would be to place on the shares an additional liability that had not existed when the debt was incurred, and thus would be to violate the contract and the due process clauses of the federal constitution.

147 On prospective overruling in general, see Bender, The Retroactive Effect of an Overruling Constitutional Decision: Mapp v. Ohio, 110 U. PA. L. REv. 650 (1962); Currier, Time and Change in Judge-Made Law: Prospective Overruling, 51 VA. L. REv. 201 (1965) ; Note, 71 YALE L.J. 907 (1962). Linkletter v. Walker, 381 U.S. 618 (1965), held, in effect, that Mapp v. Ohio, 367 U.S. 643 (1961), was retroactive only in the secondary sense. See generally Galbraith, Linkletter, Shott and the Retroactivity Problem in Escobedo, 64 MrcH. L. REv. 832 (1966) ; Mishkin, The High Court, the Great Writ, and the Due Process of Tinte and Law, 79 HaRv. L. REv. 56 (1965).

A sensitive analysis of the factors relevant to the desirability of prospective overruling is given in Currier, supra. Prospective overruling is simply one judicial technique for solving intertemporal choice-of-law problems. By deciding to make an overruling decision operate prospectively only, a supreme appellate court chooses the prior law to apply to cases arising under prior law (in the sense of coming to litigation as well as being based on events occurring under the prior law) even to the point of choosing that fornier law to apply to the case at 
Private agreements, such as ordinary contracts, sometimes operate either prospectively, by attaching legal consequences only to future events, such as breach of a new obligation, or retroactively, by attaching new legal consequences to past events, or both. Legal rules established by a self-governing institution, such as a corporation, have similar patterns of temporal scope and application. ${ }^{148}$

In sum, institutional and private rule-1naking, like legislation, usually operates prospectively, while court decisions more commonly have characteristics of retroactivity. The application of legal rules not expressed at the time the behavior or events took place is more tolerable if this application occurs in case-by-case adjudications in which a hearing of individual arguments precedes the decision and in which precedents and rules can be distinguished if they are inapt. As a general matter, therefore, retroactivity should not be discussed, and rules of retroactivity should not be formulated, in the abstract. Rather, the discussion must be placed in a specific context where such factors as who is doing the law making or changing, to whom, and with respect to what can be considered. Precedents and arguments from other contexts are no better than analogies whose applicability must be tested by a functional examination of similarities and differences in the contexts.

\section{A. Who is Doing the Larmaking and To Whom?}

When the application of new law (the lex praesens) to the consequences of earlier events changes not only the relationship between a single individual and the government, or his individual economic or political position, but also relationships between that individual and others, special disadvantages of retroactivity are presented. If, for example, the lex praesens is applied to an earlier contract, tort or property conveyance in which two or more persons are involved, not only may the reliance or expectation interests of some or all the individuals be frustrated, but they may be frustrated unequally so that their positions vis-à-vis one another are altered. It is one thing to change the rules of a game while it is being

hand. One of the five factors Professor Currier emphasizes in his analysis is the image of justice. Other factors he perceives (equality, reliance, stability, efficiency in the administration of justice) also bear importantly on the sense of injustice as a component of the decision on temporal scope of a judicial decision. See, e.g., id. at 234-52.

148 For example, if a new rule about voting or stock transfers or pre-emptive rights made past votes, transfers or issues invahid and required that the parties return to the status quo ante, some or all of the persons affected would probably be disappointed even though they all would simply be returned to their former positions. Former elections, now invahdated, would have to be repeated; stock transfers or issues, now voided, would leave sellers and buyers to deal again (and afresh) or to go separate ways. On the other hand, if the new rule is retroactive only in the secondary sense, it will not undo the prior events directly. It will, however, alter the values obtained by those events, or other of their legal consequences. 
played when the effect is simply to change the nature of the game for everyone. It is another to change the rules in such a way that one player is inaterially disadvantaged. The one particularly disadvantaged will then feel not only that his expectations have been frustrated but that he has been treated unequally in comparison with the other participants in the transaction. Hence a particularly vulnerable case for applying the lex praesens rather than the prior law (lex praeterita) is any contractual or investment situation in which a small number of people have continuing relations. ${ }^{148}$

\section{Close Versus Publicly Held Corporations}

Retroactive lawmaking often operates unequally when articles of incorporation or bylaws are amended. The problems of mequality tend to become accentuated as the corporations affected become more closely held. ${ }^{160}$ Admittedly, if amendments are enacted by a statutory majority of many shareholders in a publicly held corporation, the minority's feeling of being unfairly disadvantaged may be intensified when it compares its losses with the benefits to the majority. However, since the typical public corporation is controlled by the management, the small investor has virtually no role in governing the corporation. His reliance or expectation interests, if any, in the articles of incorporation, or the corporation law in effect at the time of his investment, would therefore be negligible as conpared with the other factors determming his investment decision. $\mathrm{He}$ resembles a lender whose main interests are financial.

In a closely held corporation, on the other hand, important reliance and expectation interests can be developed on realistic and rational bases. ${ }^{161}$ For exaniple, assume the following situation (much like that

140 In the case of a contract, the two contracting parties have voluntarily, more or less, chosen to establish specified legal relationships consisting of rights and duties between them. If their relationship with respect to the contract is later changed by application of law that was not in effect (or not foreseeable) at the time of the contracting, and if they are not disadvantaged equally, the disadvantaged party may feel the injustice particularly because he is confronted with the immediate comparison of his own situation with that of the person with whom be contracted.

${ }^{150}$ The $T u-V u$ opinion was insensitive to the differences between a corporation that is closely held and one that is publicly held. California, like the majority of states, used the large, publicly held corporation as a model for purposes of drafting its corporation law. In Bechtold, since the actuaities of the situation differed sufficiently from the model the court discarded the public corporation model in favor of a conception of a close corporation closely akin to the partnership. In $T u-V u$ the court adhered to the public model and rules apppropriate to it. See text accompanying notes 29-51 supra.

151 Reliance in this contest refers to the kind of decision making that is affected by conscious knowledge of the factor which is relied upon. In a close corporation investors quite commonly investigate the state of relevant law (such as the law of pre-emptive rights or cumulative voting) and negotiate, draft and invest only if that law is satisfactory.

Unconscious dependence on the law may create expectations much like those resulting 
in $T u-V u):$ One shareholder owns forty per cent of the stock and another owns sixty per cent; a statutory majority for most shareholder votes is a simple majority, but a two-thirds vote is required to amend the articles of incorporation. The majority shareholder can predict that he can control all matters involving a shareholder vote which do not require amendment of the articles; and the minority shareholder can confidently rely on being able to block any change that requires amendment of the articles. If the statutes are then amended to reduce the required vote for amendment of the articles from two thirds to a simple majority, they will deprive the forty per cent holder of his veto power. ${ }^{152}$ Apphication of the amended corporation law will affect him and the majority shareholder very unequally. This contrasts sharply with the relatively mimimal impact of the same law on the minority shareholder of a publicly held corporation.

\section{Legislative Versus Shareholder Change of Law}

If a corporation with widely diffused ownership is to be governed by its "owners" at all, a democratic model of decision-making is sensible. The judgment of the majority may rationally be presumed to be the best on any given issue, as an operating principle. If a simple or two-thirds majority of common shareholders of such a corporation wish to impose new transfer, voting or pre-emptive restrictions on their shares, each of them evidently has decided that the benefits to himself will outweigh the costs. All the shareholders-both those in the majority and those voting against the measure-are similarly situated vis-à-vis each other, and all will bear approximately equal, or indistinguishable, costs (such as restricted transferability or diminished voting rights of their sliares) to achieve their common or corporate, similar or disparate purposes. Even if some shareholders happen to be especially disadvantaged, they at least have had an opportunity to try to persuade a majority to vote their way. Though they lose on this issue, they may find themselves in a majority

from reliance. The free transferability of stock in a close corporation like that in $T u-V u$ is one example. Probably no subscriber in such a corporation or his lawyer would investigate the law of free share transferability. It is taken for granted, not "taken" at all in a delberative, cognitive sense. But free transferability is nonetheless an aspect of current law which builds expectations or a sort of reliance, no less than the pre-emptive rights and voting problems which are often researched and negotiated before being rehed upon.

"Expectation" interest, as distinguished from "reliance" interest, mvolves the type of belief, prediction or anticipation which is not accompanied by a course of action (or inaction) taken because of that expectation or prediction. A private person may thus say that he would have invested in the shares anyway, but that he fully expected a certain return or protection.

152 The same effect can flow from a statutory amendment which removes the necessity for amending articles to accomplish a change in the internal corporate law. For example, if waiver of cumulative voting or pre-emptive rights is made a permissible subject of bylaw as well as article amendment, and if-as is often the case-bylaws can more easily be amended, the minority's veto may disappear. 
some other day on some other issue. "Control" is thus lodged in a fluid majority whose composition can vary from issue to issue but whose judgment is presumed to be the best on each occasion.

The owners of a closely held corporation, especially one held by only two or three shareholders, do not constitute a shifting, neutral mass as in the case of a large publicly held corporation. Factions are bikely to develop and persist. A one-third sliarelholder in a two-shareholder corporation will be in the minority on every disputed issue. Control is lodged, not in a majority whose identity is unknown and which may slift from issue to issue, but firmly in one other man who can make decisions and exert corporate power for his own exclusive or principal benefit. Similarly, the minority's veto power in a close corporation is often lodged in a singleminded owner who tends to hoard lis power for self-interested reasons. Other shareholders may seek to undercut that power not out of interest in the prosperity of the enterprise, but because of the very different or even antagonistic stakes the different shareholders have in the enterprise.

The inequality which may result when parties in a contractual or investment relationship liave their positions altered by the application of new law is enormously increased if the power to change and apply that law is within the control of one of the few parties involved. By the same token, it is a very different matter when, on the one hand, the economic or control relationship between the majority and minority sliareholders in a closely held corporation is altered by "retroactive" application of new corporation law enacted by the legislature, and when, on the other hand, that relationship is altered by adoption of new articles by the majority sliareholder over the dissent of the minority. ${ }^{153}$

153 First of all, the sense of injustice and personal damage that the minority sharcholder feels because his position has changed for the worse by specific comparison with the majority shareholder is focused in the latter case on the majority shareholder himself. Not only has the majority benefited and the minority suffered, but it is the majority sharcholder who brought about that state of affairs rather than the somewhat less personal and immediate, and perhaps more trustworthy, neutral lawmaking institutions of the state. Furtbermore, there is a greater likelihood that a shareholder decision to apply later rules by amendment of the articles of incorporation was inade to aid the majority or injure the minority shareholder, simply hecause the decision was in the hands of the person who stood to benefit from making the decision in favor of retroactivity.

This view of the dangers of a power on the part of a private rule-making body to affect pre-existing investments and rights is reminiscent of the historical origins and contexts of prohibitions against retroactivity. Both in civil and in criminal legislation retroactive laws were associated with abuses of legislative power in connection with oppression of political minorities. See, e.g., Ex Parte Garland, 71 U.S. (4 Wall.) 333 (1867). Retroactive legislation, even more than prospective legislation cast in general terms but aimed at a selected group, can be tailored to affect particular individuals because the facts that will make them subject to the law have already occurred and are known or knowable to the lawmakers. Although courts commonly make legal rules to govern the consequences of prior events, at least some aspects of the procedures, personnel, powers and traditions of courts distinguish them from legislatures 
The differences between presumably neutral (legislative) and potentially self-interested (shareholder) changes in the law, and between their impact on consolidated factions in the close corporation instead of unformed masses of shareholders, lay at the heart of Mrs. Ashkins' unfairness argument in the $T u$-Vu case. ${ }^{154}$ When the majority shareholder imposed share transfer restrictions ostensibly to prevent Mrs. Ashkins from selling to a competitor, the restrictions in terms applied to all the outstandimg $T u-V u$ shares, including those held by the majority shareholder. But if he later decided to sell his own shares and did not want to offer them first to Mrs. Ashkins or the corporation, he could again unilaterally amend the bylaws and delete the transfer restrictions for his own benefit. This very real apprehension on Mrs. Ashkins' part highlights just what is wrong with unhindered majoritarianism in shareholder choices of law in closely held corporations - it can amount to effective autocracy.

\section{B. Choice of Corporate Laws in Temporal Conflict as Policy Decisions}

Conflict of laws in time decisions sliould be based on a policy-oriented analysis similar to current approaches to solution of conflict of laws in space problems. ${ }^{155}$ The following types of policies should be taken into consideration when a court, legislature or administrator chooses among

and guard against abuses of the retroactive power. Perhaps even the Blackstonian theory that court law is "found," not made, has helped the retroactive lawmaking of courts to find acceptance. See generally Greenblatt, supre note 144; Smith, supra note 144, at 412; Snyder, Retrospective Operation of Overruling Decisions, 35 ILL. L. REv. 121 (1940) ; cf. Calabresi, Retroactivity, Paramount Powers and Contractual Changes, 71 YaIE L.J. 1191 (1962); Mishkin, supra note 147; Slawson, supra note 144. Perhaps also the recent use of prospective overruling of constitutional doctrines acknowledges that even the procedural protections and traditions of courts do not invariably justify retroactive application of judge-made law. See, e.g., Johnson v. New Jersey, 384 U.S. 719 (1966).

I54 Tu-Vu Drive-In Corp. v. Ashkins, 61 Cal. 2d 283, 391 P.2d 828, 38 Cal. Rptr. 348 (1964).

155 See generally Cavers, The Chotce-of-Law Process (1965); Currie, Selected EsSays oN the Confutct of Laws (1963); EHREnzweig, Conflict of Laws (1962). See also text accompanying notes 12-27 supra.

In $T u-V u$, the minority shareholder, the trial court and imtermediate appellate court groped for some "super law," some constitutional rule or natural law concept which would limit the intertemporal application of new corporation bylaws and statutes. The history of intertemporal corporation law records this constant search for choice-of-law guidelines and repeated failures to find them. The contract clause, vested rights, due process and "fairness" tests-not given specific content by the fiat of a lawmaking authority-have proved to be circular at best and more often to be misleading substitutes for analysis. See text at notes $52-$ 90 supra. Courts faced with interterritorial choice-of-law problems have similarly sought after the guidance of a super law and formulated rules-without much success. Home Ins. Co. v. Dick, 281 U.S. 397 (1930), stands with little company for apphication of constitutional rules as himits in the interterritorial ehoice-of-law process. The disadvantages of rigidifying choiceof-law problems with constitutional rules or vested riglits notions is illustrated by New York Life Ins. Co. v. Dodge, 246 U.S. 357 (1918). 
laws applicable at different points in time spanning the events giving rise to the controversy.

\section{The Nature of the Law Changed}

The kind of change in law, whether made by legislature or shareholders, has a bearing on the temporal scope it sliould be given. In part, this bearing consists of the "expectability" of the change, the relianceinducing qualities of the former law, and the ease with which the parties could have protected themselves against the change had they so desired. For example, the kind of change made in $T u-V u$ arguably should be given a very limited temporal scope. Restriction of freely transferable corporate stock over a dissenting minority's vote is not the kind of change a minority investor or his lawyer is hikely to think of preventing beforehand by a provision in the articles or bylaws and a buttressing high-vote requirement. Free transferability is taken for granted.

To be sure, a high-vote requirement in the articles would have protected Mrs. Ashkins against article or bylaw amendment. She did not condition her investment on sucli a clause. But if there were no affirmative provision in the articles she wanted to protect by a veto, the need for a higll-vote requirement would be quite hidden. In general, investors should more readily be held responsible for the use of high-vote clauses to protect against removal of a desired clause than to protect against insertion of undesired clauses. Similarly, investors may be expected to be less aware of the necessity to protect against a provision which would counteract the normal legal consequences of the investment than to protect against a change in a provision which itself alters the normal legal consequences but which the minority needs to make its noncontrol position tolerable.

\section{Discrimination Among Rights Altered}

Some rights in shares of corporate stock deserve protection against application of subsequent shareholder or legislative law. A compelling showing of public policy in favor of applying the later law shoud be required by courts or corporations commissioners to justify destruction of such rights. Other kinds of shareholder rights, whicl are less inherently a part of the ownership of stock, can more freely be allowed to be affected by subsequent law. The usual incidents of corporate stock ownership might even be located along a continuum from basic or essential at one end to fringe or incidental riglits at the other. The kinds of rights which would appear at the essential or protected end of the scale would be those which are inherent in most property ownership: free transferability, control, and full participation in economic values. In terms of corporate stock, the basic mcidents of ownership include voting rights, pre-emptive rights, 
ordinary or equal dividend and liquidation rights, and freedom from restrictions on alienation. These are the rights or interests most important to investors. At the other end of the scale, in the category of incidental or fringe benefits, he the special preferences or privileges which usually inhere in corporate stock only if they are affirmatively provided by the express terms and conditions of the stock. Examples of such incidental riglits are special dividend or hquidation and redemption preferences, sinking fund provisions, first options to purchase stock offered for sale by shareholders, and special voting rights. ${ }^{156}$

\section{Public and Corporate Interests in Change of Law}

A significant public interest underlies retroactive application of some provisions of corporate law. Similarly, greater corporate benefit will flow from retroactive application of some article and bylaw amendments than others. There are sound policy reasons for allowing majority shareholders to apply some amendments retroactively without obtaining unanimous consent and the attendant danger of "holdups" or "strike suits" by dissenters. ${ }^{157}$ For example, if mandatory cumulative dividends are accorded to shareholders by the articles of incorporation and have accrued over a period of years, their elimination may be essential for the corporation to raise new capital and establisl a firmer economic foundation. Since the state has an interest in the economic prosperity of corporations, the state corporation law might appropriately provide for amendment of the articles of incorporation by majority shareholder vote to eliminate the riglit to these accrued dividends even though the amendment was adopted after the shares had been purcliased and the dividends had accrued. Here there is a strong corporate interest in the amendment and a justification to state policy in favor of applying subsequent law to alter the legal consequences of investment in the stock of the corporation. ${ }^{158}$

$158 \mathrm{~A}$ pure contract analysis would entitle these terms to all the protection afforded more fundamental rights. The history of intertemporal corporation law reveals, however, that this imphication is what makes contract law thinking unsuitable when pressed in the corporate context.

157 Some form of majority control, in other words, seems so central to the present model of the corporate institution that it must be taken as a starting point. Furthermore, some aspects of shareholder control are so central to that model that when the model unust be changed by legislation, a dissenting shareholder should not be heard to complain. In Maddock v. Vorclone Corp., 17 Del. Ch. 39, 147 Atl. 255 (Ch. 1929), the court mappropriately used the model of a publicly held corporation, and the premises on which laws geared to such a corporation are based, to solve a closely held corporation problem involving amendment of articles on voting rights. The awkwardness of applying these premises to the situation is evident in the opinion.

158 Perhaps it is on this kind of analysis that shareholders affected by subsequently enacted "strong arm" clauses in merger statutes have been summarily stopped in their attempts to invalidate a "freeze-out" based on an intertemporal argument. For example, in Belofi v. 
In contrast, if a legislative or shareholder amendment will change the rights of shareholders in respects not important to the state or to the corporation as an institution, justification for applying subsequent law is relatively lacking. If the purpose of a shareholder amendment is simply to enrich majority shareholders at the expense of minority shareholders, ${ }^{150}$ or otherwise to alter the control or investment relationships among the

Consolidated Edison Co., 300 N.Y. 11, 87 N.E.2d 561 (1949), a 1936 amendment to the New York Corporation law allowed utilities to merge with ninety-five per cent owned subsidiaries without a sharelıolder vote and without provision for continuing minority shareholders in the consolidated enterprise. The court upheld the statute against attack by a shareliolder who purcliased his shares in 1928. In Alpren v. Consolidated Edison Co., 168 Misc. 381, 5 N.Y.S.2d 254 (Sup. Ct. 1938), a shareliolder of the parent advanced an intertemporal argument that the statute's effect was to deprive him of a pre-existing vested riglit not to have his corporation merge with less than a wholly owned subsidiary. The court concluded that the statute affected but a "slight modification" of the pre-existing statutory expectations and that "constitutional prolnibitions ... operate only to safeguard substantial rights and interests, not some imagined advantage." Id. at $383-84,5$ N.Y.S.2d at 256 . There was some justification for the Beloff and Alpren decisions in that a precondition to a merger under the statute was approval by the State Public Utility Commission. See Note, 54 Nw. U.L. Rev. 629, 636 n.33 (1959). The decision to eliminate the minority was not left solely to the judgment of an interested majority shareliolder. See text accompanying notes 149-54 supra. However, as regards the ordinary business corporation, the requirement of an independent agency's approval was climinated by statutory amendment in 1949 which extended the strong-arm power to all corporations witb ninety-five per cent owned suhsidiaries. See N.Y. Bus. CoRP. LAW \& 905. A strong intertemporal argument could be made by a minority being squeczed out of an ordinary business corporation in New York, but no case since Beloff has arisen to challenge the statute on intertemporal grounds.

Delaware's strong-arm statute, DEx. CoDE ANs. tit. 8, § 253 (Supp. 1964), enacted in 1957, was challenged in Coyne v. Park \& Tilford Distillers Corp., 38 Del. Cb. 514, 154 A.2d 893 (Sup. Ct. 1959). There the "overriding answer" to plaintiff's contention that the statutc was unconstitutional as to him hecause lie acquired his shares before its enactment, the court said, "is the reserved power of the state to amend corporate charters." Id. at 521, 154 A.2d at 897. The court cited the Beloff decision without mentioning the requirement of prior approval by a state agency.

Voege v. American Sumarata Tobacco Corp., 192 F. Supp. 689 (D. Del. 1961), indicates by dictum its concurrence with the result reached in Coyne. However, the subsequent disposition of the Voege case, 241 F. Supp. 369 (D. Del. 1965), suggests another dinension of the intertemporal problem. The court licld that the facts alleged stated a violation of Rule $10 \mathrm{~b}-5$ of the federal Securities Exchange Act of 1934 in that the merger amounted to a salc and, according to the plaintiff's allegations, was taimted with fraud. In particular, the court said that plaintiff, when purchasing her stock in 1945, relied on law requiring the company to treat lier fairly. While corporate mergers theoretically were subject to a fairness or fraud test at that time and therefore plaintiff's reliance was justified, enactment of the strong-arm clause effectively dispensed witl tle limits on majority power. See Stauffer v. Standard Brands, Inc., 41 Del. Ch. 7, 187 A.2d 78 (Sup. Ct. 1962). Traditional "reserved power" analysis would conclude from the enactment of $\S 253$ of the Delaware Corporation Law that plaintiff's reliance should be disregarded, particularly where the legislature rather than the corporation was responsible for the change. Insofar as the federal securities law is concerned, however, a minority sliareliolder's reliance at the earlier time may, if worthy of protection, restrict the reserved power concept. See also note 89 supra.

159 See, e.g., Faunce v. Boost Co., 15 N.J. Super. 534, 83 A.2d 649 (1951). 
shareholders, often no corporate or public benefit is directly presented to outweigh the unfairness to the minority. ${ }^{160}$

\section{Other Considerations}

Differences between closely held and publicly lield corporations, and differences between legislative and shareholder lawmaking discussed earlier, similarly call for a system which regulates the rule-making and rule-changing functions appropriately to balance the interests of all concerned. ${ }^{161}$ Examination of $T u-V u$ lias indicated that although majority shareliolders when amending articles or bylaws in accordance with the statute are thought to exercise the reserved or inherent power of the state to which all shareholders submitted at the time of investment, application of such amendments by majority shareholders to outstanding shares should be viewed with far greater suspicion on the part of the courts and corporations commissioners than application of statutory or decisional corporation law. For, wliether or not apphication of the les praesens be called "retroactive," the intertemporal law decision by the state is presumably disinterested; that is, it is made with a kind of neutrality and generahity of application that is lacking in the case of amendment by a majority shareholder. Similarly, amendments affecting previously issued shares in a close corporation should be viewed with a greater suspicion than amendments in publicly held corporations. In the closely held corporation, ${ }^{162}$ there is a much greater likelihood that retroactive application of the law in the secondary sense) will materially alter a power balance struck after deliberation, and perhaps negotiation, in rehance upon existing law and in the expectation that the relationships will continue to be what they were when first established.

Above all, the purpose of the new law should be examined to ascertain what temporal scope will best accomplish its aims. If at the time of decision there is no purpose to be promoted by applying the new law to corporations which have selected antecedent connections with prior law, the conflict between lex praesens and les praeterita may be, in a sense, a false

${ }^{160} T u-V u$ can be understood more readily if the threat of a competitor's purchase of sbares is taken seriously. The corporate benefit from barring hostile interests outweighs the individual disadvantage to Mrs. Ashkins, in the supreme court's balance. And Bechtold can be reconciled with $T u-V u$ on the ground that no corporate benefit was shown to be likely to follow from removal of the share transfer restrictions. At most an individual benefit to the majority would result, and that was outweighed by the individual loss to the minority and, perhaps, the corporate damage if hostile interests were to buy im.

161 Surely the fact that California law pernitted the majority in $T u-V u$ to change the bylaws without any meeting or vote, much less notice and a hearing before the corporations coinmissioner, makes the free-ranging majoritarianism of that case particularly dangerous.

162 See text accompanying notes 150-52 supra. 
conflict. Some legislation or charter amendments to be effective must be applied to all existing and future corporations, regardless of antecedent connections. ${ }^{163}$ Other changes in the law, for example, changes in presumptions about pre-emptive rights or cumulative voting, need not be applied to pre-existing corporations to accomplisl their purpose, a purpose addressed inplicitly to the formation process rather than amendment. In other words, corporation code sections which authorize amendments to articles and bylaws should not automatically be geared to sections authorizing contents of original articles. The two slould overlap only when the purpose of each section legitimately requires the same teinporal scope as the other.

\section{CONCLUSTON}

The basic policy conflict that gives life to the conflict of laws in time arises froin the competition between the desirability of protecting legitimate rehance interests and the need for freedoin to make changes and improvenents in the law which, in some instances, may defeat or frustrate those reliance interests. Systematic resolution of this conflict requires that the legal structure address itself to two goals. First, it should protect legitimate individual rehance interests except when they are outweighed by interests in applying new legal rules. Second, the law should encourage the creation of reliance interests only when they probably will be upheld; it should strive to discourage the creation of illegitimate or unprotectable reliance interests, and those which are likely to be frustrated by subsequent rules whose application to controversies rooted in prior law will be given prinacy.

In corporate law, systems for testing the balance between old and new rules have at least a double task: balancing old against new public (legislative, judicial, and administrative) rules, and balancing old against new private (shareliolder and director) rules. Courts-the natural forum for adjudicating legislative or private choices of law-have largely withdrawn their constitutional, vested right and fairness limitations on legislative and shareholder majoritarianisin. As a result, most of the burden has been placed upon the legislatures, which have responded by creating some safeguards. Escape valves such as dissenters' appraisal rights, ${ }^{164}$ protection for

${ }^{163} \mathrm{New}$ legislation or article amendments on voting, share transfers or pre-emptivo rights need not apply to prior elections, transfers or issues. In contrast, new legislative or article provisions on dividends may sometimes have to apply to past, accrued dividends to accomplish the purpose of the new law.

164 See, e.g., CAL. CORP. CODE $\$ \S 4300-18$ (dissenters' appraisal rights on merger or consolidation). 
the integrity of the shareholder electoral process, such a proxy rules, ${ }^{165}$ and some self-limitations, such as express limits on retroactive application of legislation, have been provided. In addition, other nonjudicial institutions liave been created as safeguards. ${ }^{166}$ But even the combination of these safeguards has not invariably proved sufficient to prevent unnecessary destruction of private rehance interests by circumscribing the power of majority shareholders to impose their own intertemporal choices of law on a dissenting minority. ${ }^{167}$

165 See, e.g., CAL. CoRP. Code $\$ 3637$; Securities Exchange Act $\$ 14$ (a), 48 Stat. 881 (1934), 15 U.S.C. $\& 775$ (1964), and Regulations 14A and 14C thereunder.

166 See, e.g., CAL. CoRp. CODE $\$ \S 25300-19$ (establishing the Division and the Commissioner of Corporations).

187 If broad majority rule is to be retained as the model for corporate government, the vulnerability of rules to change should be emphasized to minority investors to stimulate them to consider and employ such protective techniques as they deem necessary. This warning could he partly accomplished by a statutory requirement that the articles of every corporation contam an express description of the reserved power of the state and of the majority shareholders. This kind of reserved power clause is sometimes included by corporate draftsmen representing majority interests to ensure that there will be no unexpected limit placed on the amendment power. See, e.g., Maddock v. Vorclone Corp., 17 Del. Ch. 39, 147 Atl. 255 (Ch. 1929). Such a reservation can be cast in language like the following:

Any and every statute of the State of $\longrightarrow$ heremafter enacted, whereby the rights, powers or privileges of corporations or of the shareholders of corporations organized under the laws of the State of - are mcreased or diminished or in any way affected, or whereby effect is given to the action taken by any number, fewer than all, of the shareholders of any such corporation, shall apply to the Corporation and shall be binding not ouly upon the Corporation but upon every shareholder of the Corporation to the same extent as if such statute had been in force at the date of filing these Articles of Incorporation of the Corporation in the office of the Secretary of State of -

A required restatement of shareholder amendment powers as set forth by statute, or a departure from the statutory percentages where valid, would also serve as a reminder to minorities of the temporary nature of internal corporate rules. One form for such an amendment provision is the following:

Notwithstanding any provision of the (Corporation Code) now or hereafter in force requiring for any purpose the vote, consent, waiver or release of the holders of shares entitling them to exercise (two-thirds), or any other proportion, of the voting power of the Corporation or of any class or classes of shares thereof, such action, unless otherwise expressly required by statute or by these Articies, may be taken by vote, consent, waiver or release of the loolders of shares entitling them to exercise a (simple majority) of the voting power of the Corporation or of such class or classes.

Although these mandatory article provisions would warn investors that existing articles might be deleted or changed, they would not notify minority shareholders of the possibility of amending bylaws or the changes that might be made, as in $T u-V u$, by inserting new articles on topics previously unmentioned.

Another characteristic of corporations fortunately affords one way of counteracting these dangers. Because corporations can be formed only by filing articles with the state, the state 
Rules about retroactivity have been discussed in the abstract and applied with little sensitivity to the key questions: How retroactive? Retroactive with respect to what events? By whom is the retroactive law made? Some legislation and some court decisions appear to be shaped by implications of clianges in law through time, but the shaping factors have not been sufficiently isolated and discussed. Apparently a governing theoretical structure is lacking. Hopefully by freeing itself from outmoded conceptualism and by casting the problems in terms of intertemporal choice of law, ${ }^{168}$ a new analysis can draw attention not only to relevant

can exercise some supervision over the original understanding of the parties. Using this power, the state can force the investors to confront the implications of their reliance on existing law, to the extent the articles are involved. The state could declare that the most important shareholder interests, sueh as dividend, liquidation, voting, transfer and pre-emptive rights, could be governed only by articles, not by bylaws (or that bylaws too inust be publicly fled to become effective) and that original and amended articles of every corporation must spell out all the terms of such sliareliolder riglits to qualify for filing.

A requirement that the articles of each corporation set forth all important financial and control rights of shareholders, whether such rights differ from those otherwise provided by law or not, together with a description of the votes and procedures for amendinent, would remind shareholders of the riglits that are important to them and of the manner by which these riglits can be altered. The philosoply of such a statute departs from that of current corporation laws which provide a statutory model of the corporation, patterned after the publicly held company, and grant permission to vary the model in some respects by specific provisions in whose absence the statutory inodel prevails. Under the proposed law, organizers of the corporation would liave to make decisions on all major topics with respect to which the state allowed a choice, and would liave to set forth those decisions together with the major terms supplied by state law (as to which no individual variation is permitted). In addition, because the most important terms of slareholder rights would be spelled out in each set of articles, an amendinent to the state corporation law would not change those rules in a given corporation, unless the statute were mandatory, in which event all corporations would be affected alike. See text accompanying notes 130-43 supra.

This specific statutory recommendation is mentioned only to illustrate a consequence of focusing on time problems in corporate law. That focus can result both in protection of reliance interests when they outweigh the need for change and in the prevention of unprotectable reliance. Its usefulness, lowever, depends on imquiry into the ways private investors rely on contemporaneous law when making investment decisions. It also must recognize the implications of changes in the law over time and the problems created by failing to make clear the intertemporal scope of new law.

A statutory solution such as this may, lowever, create problems as well as solve them. By requiring investors to think about problems, the odds of whose occurrence are low, it may cause more negotiations to "blow" than are worth jeopardizing for the sake of protecting some inimorities who otherwise would be abused. Also, the expense of additional lawyering cannot be disregarded. But a simple form for articles concerning the topics whose coverage is mandatory, with alternative provisions suggested, could be published by the state to ease the drafting and decision-making process. (However, if these provisions become "boiler plate", the statute will have failed in its purpose-to put investors on notice, in a useful way, of the implications resulting froun change in law over time.)

168 The intertemporal choice of law question may, as indicated earlier (see note 13 supra) be coupled with an interterritorial choice-of-law question. If, for example, state $A$ is the forum and state $B$ is the state of imcorporation of a corporation whose slareholders are disputing the validity of an amendment to the articles of incorporation, state $A$ will probably 
interests at stake but also to possible means by which those interests can better be integrated or balanced.

choose to apply the corporation law of state $B$ to the dispute. But, the intertemporal question then is should state $A$ apply the corporation law of state $B$ as it appeared at the time the articles were amended, or as it stood at the time the corporation was organized in state $B$, or when the dissenters bought their shares in state $B$ (assuming a difference in the law at those times) ? As a general inatter, the reference of forun $A$ to the law of state $B$ should be treated as a reference to the transitional rules of state $B$. Therefore, if state $B$ would apply its law in effect at the time of the article amendment, state $A$ should do likewise. This is true even if state $A$ in a domestic case involving a corporation organized in state $A$ would take a vested rights approach or construe its reserved power clause differently or apply a fairness test which would compel the choice of the law at the time of incorporation or investment. Like a federal court in a diversity case, the forum ought to apply the intertemporal rules of the jurisdiction whose substantive law is selected by the territorial conflicts rules of the forun as they exist at the time of decision. State $A$ should not, it would seem, automatically apply its domestic intertemporal choice of law or transitional rules to every interstate, intertemporal case. This is simply to acknowledge that transitional rules result from the application, interpretation or construction of substantive law rules. If the forum's territorial choice-of-law policy at the time of decision is to apply $B$ 's law, it should be irrelevant that the forun had a different territorial choice-of-law rule at an earlier time. Similarly irrelevant is the fact that the forum gives a different temporal scope to its own corporation law or reserved power clause.

A case apparently taking the approach advocated here but without discussion in these terms is State ex rel. Starkey v. Alaska Airlines, Inc., 68 Wash. 2d 297, 413 P.2d 352 (1966).

The intertemporal problems in territorial conflicts cases are not invariably parallel to the single jurisdiction intertemporal cases or the straight interterritorial conflicts cases with no intertemporal conflict. For example, if a court in state $A$ las a case involving a cause of action under the law of state $B$ and is concerned with whether to apply the statute of limitations of state $A$ which would permit the action or the shorter period of state $B$, the state $A$ court may appropriatcly inquire (in the terms customary for these questions) whether the state $B$ limitation is part of the "right," and hence intended to qualify the right of action, or whether it is a separate limitation which can give way to state $A$ 's law. But if a court in state $A$ is presented with an attempt by the legislature of state $B$ to extend its limitation period (or if the state $A$ court bas a case arising under the state $A$ law, and state $A$ has extended the limitation period), the question is to what extent the legislature of the state which created the cause of action may change its own mind about the limitation period and may revive barred claims (or, in reverse, bar claims by a reduction in the limitation period). Questions of deference to a foreign sovereign or reliance on the law of another state are thus lacking in the single jurisdiction cases. 